Review

\title{
Development of Carbon Fiber-Reinforced Thermoplastics for Mass-Produced Automotive Applications in Japan
}

\author{
Yi Wan * and Jun Takahashi
}

check for updates

Citation: Wan, Y.; Takahashi, J.

Development of Carbon

Fiber-Reinforced Thermoplastics for Mass-Produced Automotive

Applications in Japan. J. Compos. Sci.

2021, 5, 86. https://doi.org/10.3390/ jcs5030086

Academic Editor: Francesco Tornabene

Received: 9 February 2021

Accepted: 9 March 2021

Published: 22 March 2021

Publisher's Note: MDPI stays neutral with regard to jurisdictional claims in published maps and institutional affiliations.

Copyright: (C) 2021 by the authors Licensee MDPI, Basel, Switzerland. This article is an open access article distributed under the terms and conditions of the Creative Commons Attribution (CC BY) license (https:// creativecommons.org/licenses/by/ $4.0 /)$
Department of Systems Innovation, the University of Tokyo, Hongo 7-3-1, Bunkyo-ku, Tokyo 113-8656, Japan; takahashi-jun@cfrtp.t.u-tokyo.ac.jp

* Correspondence: wan-yi@cfrtp.t.u-tokyo.ac.jp

\begin{abstract}
The application of carbon fiber-reinforced thermoplastics (CFRTPs) for automotive mass production is attracting increasing attention from researchers and engineers in related fields. This article presents recent developments in CFRTPs focusing on the systematic development of lightweight CFRTP applications for automotive mass production. Additionally, a related national project of Japan conducted at the University of Tokyo is also introduced. The basic development demands, the specific requirements of CFRTPs for lightweight applications in automotive mass production, and the current development status and basic scientific outputs are discussed. The development of high-performance CFRTPs (chopped carbon fiber tape-reinforced thermoplastics (CTTs)) and functional CFRTPs (carbon fiber mat-reinforced thermoplastics (CMTs)) is also introduced. The fabrication process control of CTTs is evaluated, which demonstrates the extreme importance of the mechanical performance. The ultralight lattice, toughened structures, and orientation designable components of CMTs provide a flexible multi-material solution for the proposed applications. Moreover, highly efficient carbon fiber recycling technology is discussed, with recycled carbon fibers exhibiting outstanding compatibility with CFRTPs. A cost sensitivity analysis of carbon fiber and CFRTPs is conducted to guarantee the feasibility and affordability of their application. This article also discusses the trends and sustainability of carbon fiber and CFRTPs usage. The importance of the object-oriented optimal development of CFRTPs is emphasized to efficiently exploit their advantages.
\end{abstract}

Keywords: plymer-matrix composites (PMCs); recycling; compression molding; thermoplastic resin

\section{Introduction}

Carbon fiber-reinforced polymers (CFRP) have been applied to various industrial fields over the last 50 years, most commonly in the aeronautics, sports, and automotive industries. In the aeronautics and sports industries, CFRPs are fabricated to provide stiffer and lighter alternatives to conventional metallic components. In the automotive industry, the CFRP applications have evolved over time. Initially, the CFRPs were extensively used in high-end automotive racing and supercars, as they possessed unsurpassed strengthto-weight ratio and high performance. The first carbon fiber monocoque chassis was introduced in Formula One (F1) by McLaren in the 1981 season, and the first carbon fiber body shell was used in the supercar McLaren F1 in 1996 [1]. However, application of CFRPs in the automotive industry have more recently taken another direction. With increasing concerns of global warming, regulations regarding $\mathrm{CO}_{2}$ emissions have become more severe worldwide. The automotive industry is one of the primary sources of global $\mathrm{CO}_{2}$ emissions; therefore, automotive companies have focused their research on technologies that reduce these emissions [2], which has led to the development of low-emission and high-efficiency internal combustion engines, hybrid engines, fuel cell engines, and electric motors. The development of different powertrain types shows the potential of $\mathrm{CO}_{2}$ emission reduction in automotive engineering. Furthermore, weight reduction is important in all automotive applications with different powertrain types [2,3]. As reported by the Japan's Ministry of Transport, decreasing the weight of a single automobile by $100 \mathrm{~kg}$ reduces its $\mathrm{CO}_{2}$ 
emissions by an average of $20 \mathrm{~g} / \mathrm{km}$ [4]. Thus, the development and application of CFRPs for automotive weight reduction have increased significantly in recent years, aiming towards mass production opportunities.

CFRPs developed for weight reduction in automotive mass production have different material requirements than traditional CFRPs developed for performance enhancement. However, in comparison, CFRPs are still much more expensive than conventional metallic materials; therefore, cost reduction is considered the most important factor in the development of CFRPs for this application. Furthermore, the weight reduction is more effective if CFRPs can be used in different components; hence, the ability to fabricate different types of CFRPs is also important to guarantee their feasibility (Figure 1). Moreover, these lightweight materials must be used in mass-produced automobiles with over a million annual orders. Consequently, the development of high-cycle mass-production fabrication techniques for CFRPs is of unprecedented importance, with less focus on top performance [2-8].

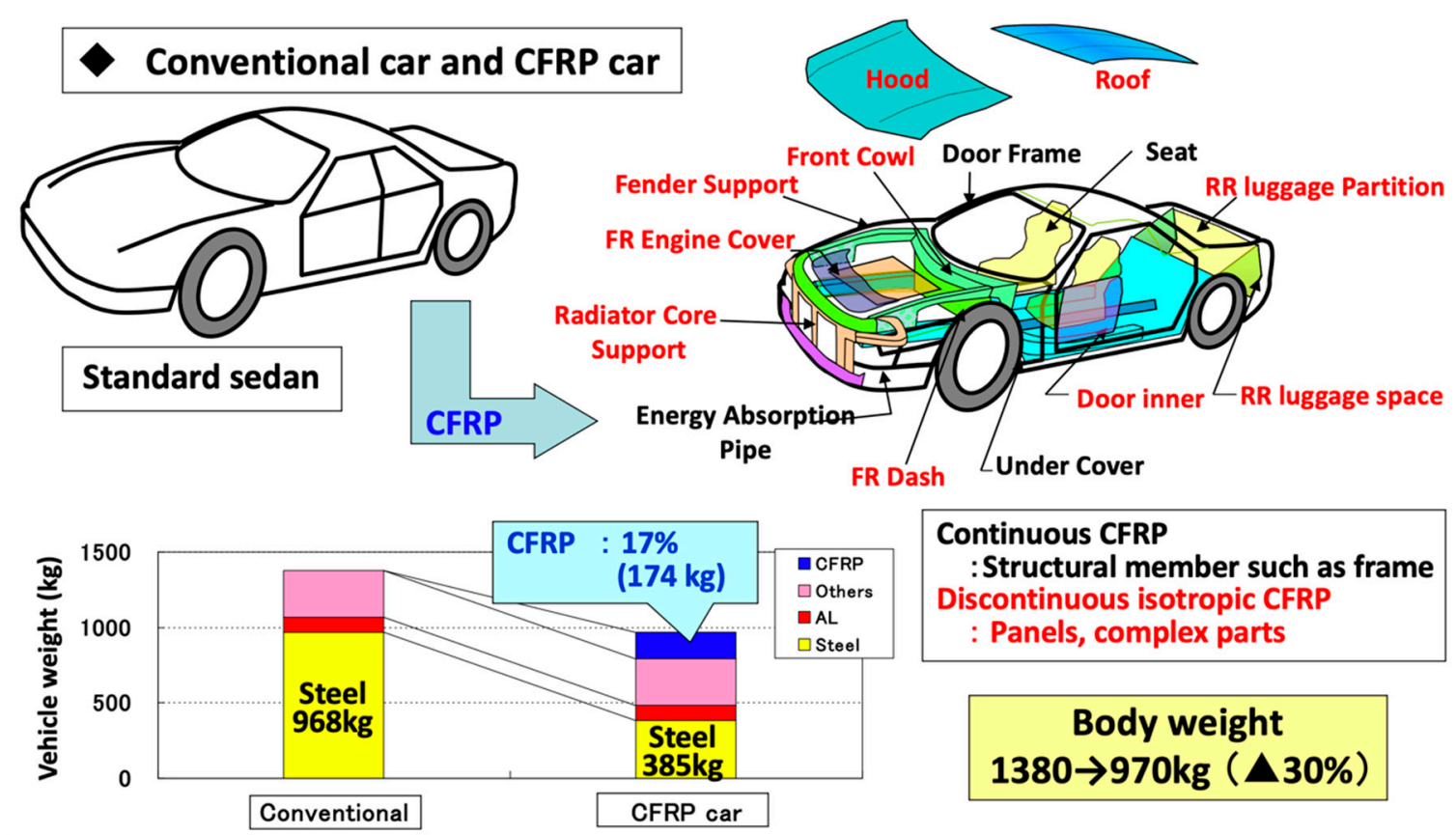

Figure 1. Weight reduction of automotive using carbon fiber-reinforced polymers (CFRPs).

CFRPs can be divided by the component matrix polymers as either thermoplasticbased (CFRTP) or thermoset-based (CFRTS). Additionally, the length of the carbon fiber is an important characteristic, and fibers can be continuous or discontinuous. The final mechanical properties and fabrication features of the resulting CFRPs are influenced by both the polymer matrix and fiber length (Figure 2). Moreover, traditional CFRPs with high mechanical performance are generally expensive, require advanced molding technologies, and longer molding times. Therefore, they cannot fulfill the new application requirements for automotive mass production, which has led to substantial development in this field. Recently, high-performance discontinuous CFRPs (e.g., carbon fiber sheet molding compounds (CF-SMC) with randomly oriented strands (ROS)) have exhibited significant potential for structural component applications by combining superior mechanical properties with complex shape formability [9-16]. Moreover, introducing thermoplastics into high-performance discontinuous CFRPs offers a solution for high-cycle manufacturing with compression molding and stamp molding. Moreover, continuous CFRPs with additive injection-molded discontinuous CFRPs [17-20] (also denoted as "overmolding") have been developed to fulfill the new application requirements. 


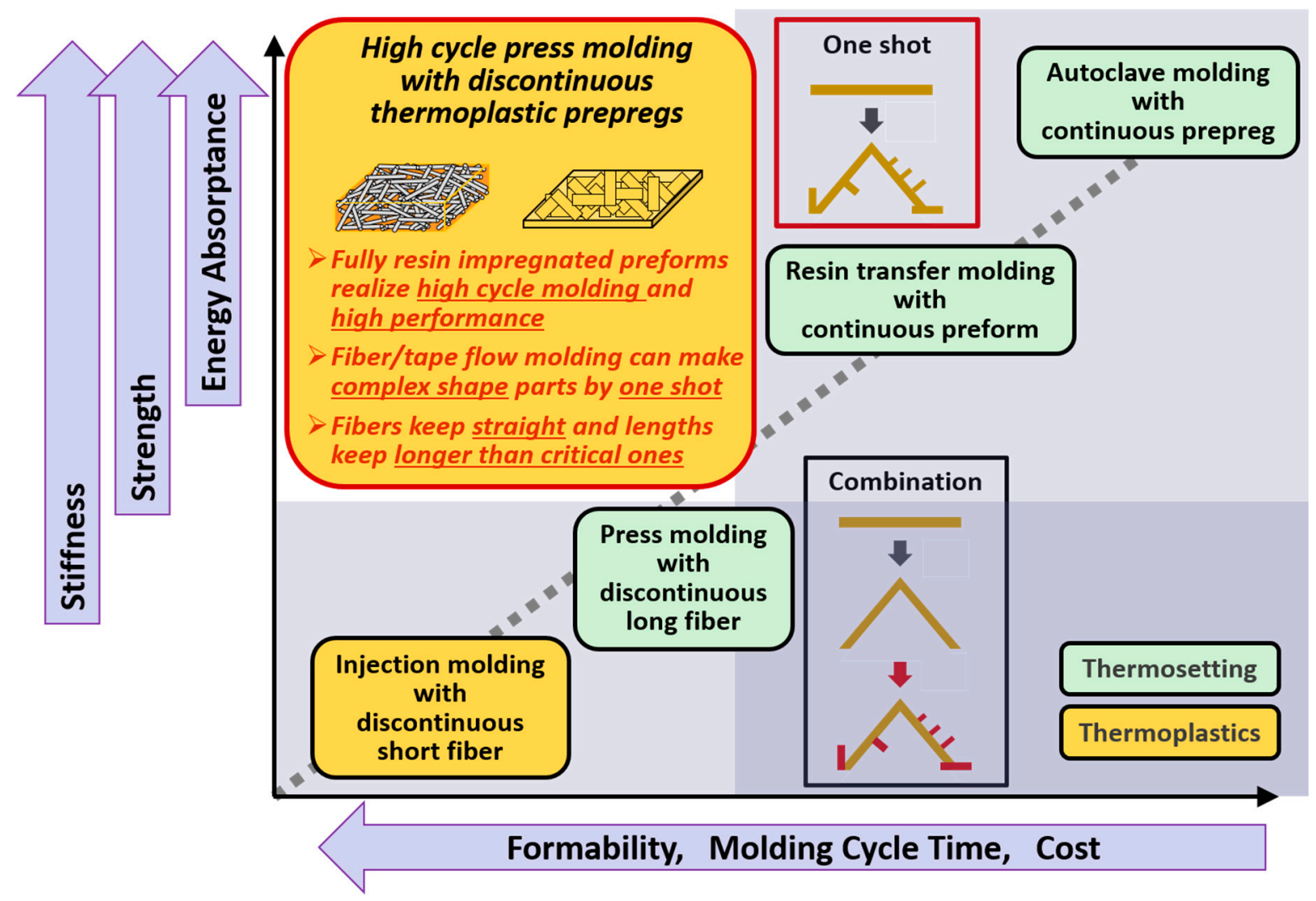

Figure 2. Development direction of carbon fiber-reinforced thermoplastics (CFRTPs) in projects aiming to realize highperformance, affordable, formable, and recyclable components [4].

A national project focusing on the systematic development of lightweight CFRTP applications for automotive mass production was launched by the Japanese Ministry of Economics and Trade and Industries (METI) in the 2008-2012 financial years. As a continuation, a second national project was organized by the University of Tokyo between 2013 and 2017 (hereinafter denoted as the "Japan's CFRTP projects") [3,5,21,22]. In these projects, discontinuous CFRTPs were developed using high-cycle compression molding technologies. The demands of lightweight applications were studied, and corresponding technologies were developed to satisfy these requirements.

Herein, the specific requirements for CFRTP applications within automotive mass production will be presented; furthermore, the current development status and basic scientific outputs in the Japan's CFRTP projects will be demonstrated.

\section{Specific Requirements for Automotive Applications}

To make automotive mass application feasible, the cost reduction of CFRPs is one of the most important challenges to be addressed. Figure 3 presents the corresponding research and development items proposed in Japan's CFRTP projects. The manufacturing costs of CFRTPs are separated into four sections: the carbon fiber, matrix resin, prepreg fabrication, and molding process. To reduce overall costs, the feasibility of the corresponding research and development items must be analyzed in detail. 


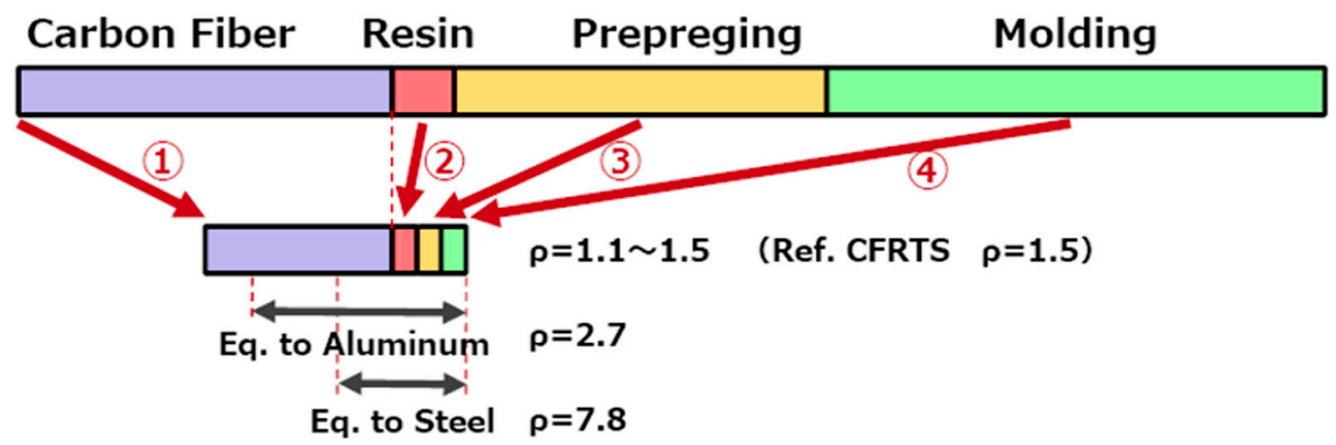

\section{Corresponding R\&D items}

(1) Innovative carbon fiber

\section{Optimal design}

Closed loop recycling

(2) Utilization technology of low cost resin

(3) Innovative prepreging

(4) Innovative manufacturing

Figure 3. Cost reduction roadmap and corresponding research and development items of CFRPs.

In Japan's CFRTP projects, discontinuous CFRTPs were selected because of their high potential to fulfill the aforementioned requirements. A cost sensitivity analysis of CFRTP with polypropylene matrix was conducted to verify the sensitivity of the cost of CFRTP automotive parts to different factors, such as the molding cycle time, cost of carbon fiber, effective usage ratio of carbon fiber during manufacturing, and volume fraction $\left(V_{f}\right)$ of carbon fiber (Figure 4$)$. The results presented an overall strategy for reducing the cost of CFRTPs. For all four factors, the most cost-sensitive part is the molding cycle time, meaning that decreasing the molding cycle time can efficiently decrease the cost of the part. In addition, the cost of carbon fiber considerably affects the cost of the parts; however, significantly lowering the cost of carbon fiber is difficult to achieve unless an innovative carbon fiber is developed. Meanwhile, the effective usage ratio of carbon fiber in CFRPs may be increased considerably by recycling waste carbon fiber directly in the plant. Moreover, an optimal structure/material design that lowers the carbon fiber $V_{f}$ will further increase the efficiency of CFRTP applications. Based on the cost sensitivity study conducted during Japan's CFRTP projects, the cost of the CFRTP parts can be reduced to the same level as those of aluminum alloys, which will be the foundation for mass application in the automotive industry.

Related studies on the aforementioned factors must be conducted to achieve mass applications and to provide solutions to the development of novel CFRTPs for automotive applications. Similarly, traditional CFRTPs used for aeronautics (with matrix resins from the polyaryletherketone family) face considerable limitations in addressing the changes required by these factors. Although the mechanical performance of the CFRTPs are excellent, and their light weight can help with weight reduction, their high cost is the most important obstacle. Additionally, the brittleness of CFRTSs originating from brittle matrix resins also limit their application feasibility in the automotive industry, where materials are required to possess high energy absorption capability. Further, conventional CFRTPs, which use resins from the polyaryletherketone family (e.g., polyether ether ketone (PEEK)), increase the component cost. In Japan's CFRTP projects, less expensive resins, such as 
polypropylene (PP) and polyamide 6 (PA6), have been investigated. The CFRTPs obtained from these projects managed to maintain mechanical performance through material design and fabrication process control. Furthermore, high-cycle molding technologies were developed to ensure the cost reduction of the CFRTP parts, and carbon fiber recycling technologies were employed to fulfill the usage ratio requirement of mass application in automotive fabrication.
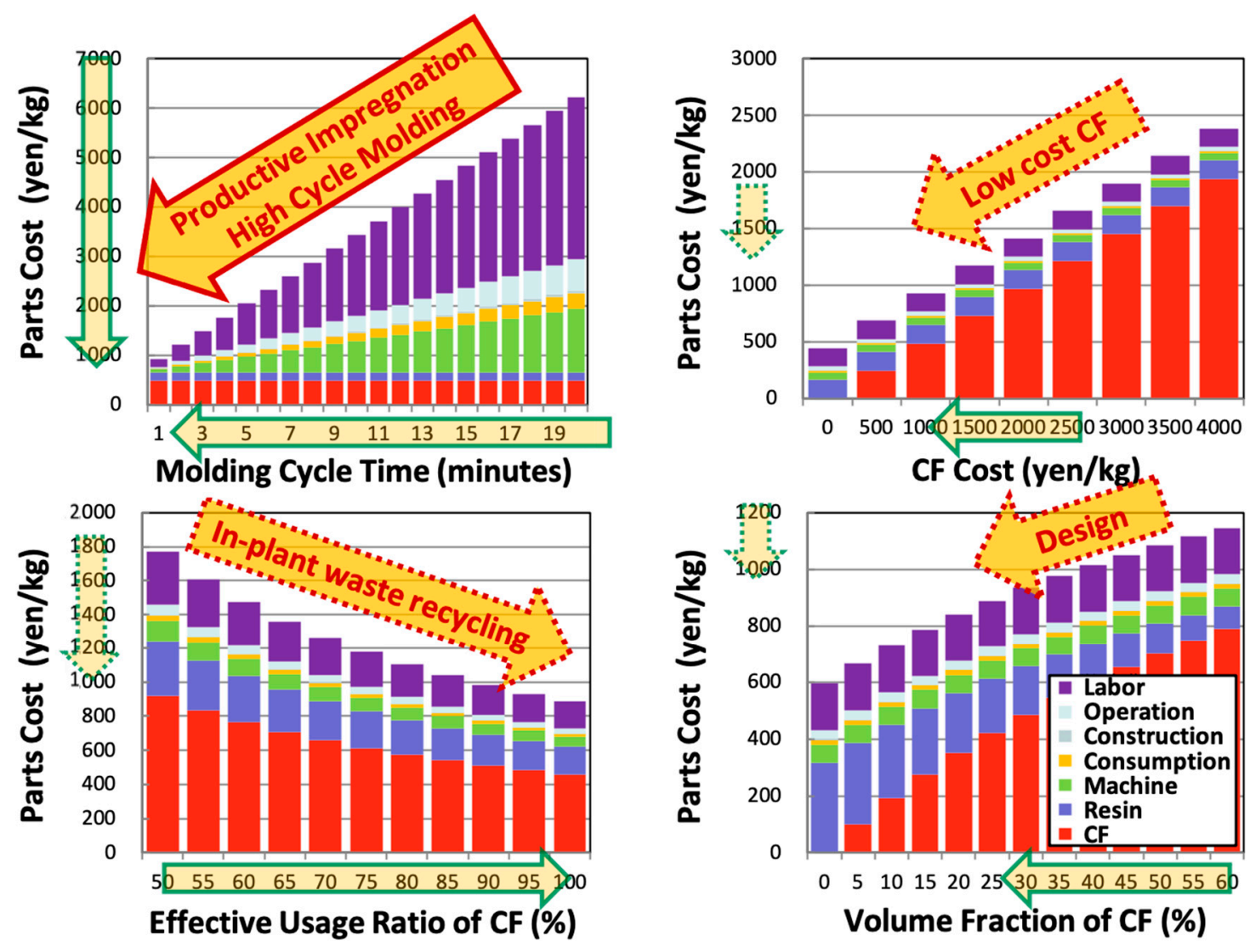

Figure 4. Sensitivity analysis of the different factors on the cost of CFRP automotive parts.

\section{Technology Developments of the CFRTP Applications}

In this chapter, the technological developments for automotive mass application are presented in detail, in addition to the two major types of developed CFRTPs. The feasibility of reaching the low cost requirement and ensuring mass application in the automotive industry is demonstrated based on different factors. Future trends and perspectives of CFRTP applications in automotive engineering are also demonstrated and discussed.

\subsection{Overview of Japan's CFRTP Project at the University of Tokyo}

Owing to severe environment and energy problems, the METI of Japan's government launched the CFRTP projects based on strong demand from Japan's automotive industries and carbon fiber manufacturers. Within these projects, specialized intermediate CFRTPs, manufacturing processes, structural optimization design, high-cycle molding, jointing technologies, and closed-loop recycling technologies have been developed (Figure 5) [23,24].

A drawback of continuous CFRP is the difficulty of forming complex shaped structures. However, the mechanical properties of conventional discontinuous CFRPs (e.g., injection molding and long fiber thermoplastic direct-molding (LFT-D)) cannot fulfill the requirements of the primary structural parts in the automotive industry. Therefore, novel specialized discontinuous CFRTP intermediate materials (semi-finished and semi-impregnated CFRTP products for mass production) have been developed, which can maintain both 
carbon fiber linearity and a sufficient aspect ratio to offer high performance, affordability, formability, and recyclability (Figure 6). Multiple CFRTPs are considered for applications to increase the effective usage of carbon fiber. Discontinuous CFRTP with outstanding mechanical performance (CTTs) [25-40], also named ROS [13], CF-SMC [9-12], etc.) can be used for primary structural members. The mat-structure CFRTPs (carbon fiber matreinforced thermoplastics (CMTs)) are divided into carbon fiber paper-reinforced thermoplastics (CPTs) [41-51] and carbon fiber card web-reinforced thermoplastics (CWTs) [52-59]. These exhibit increased functionality owing to the ultralight lattice components, toughened sandwich structures, and orientation-designable intermediates that can provide flexible application options. Moreover, novel recycling technology, as discussed below, may ensure the fabrication of discontinuous CFRTPs with recycled carbon fibers.

\section{Intermediate materials}

Establishment of material design technology to meet the demand from properties, $C A E$, etc.

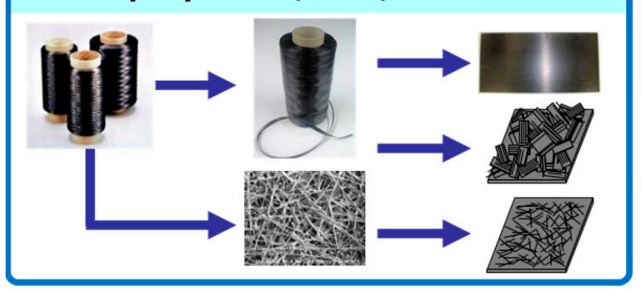

Evaluation and design

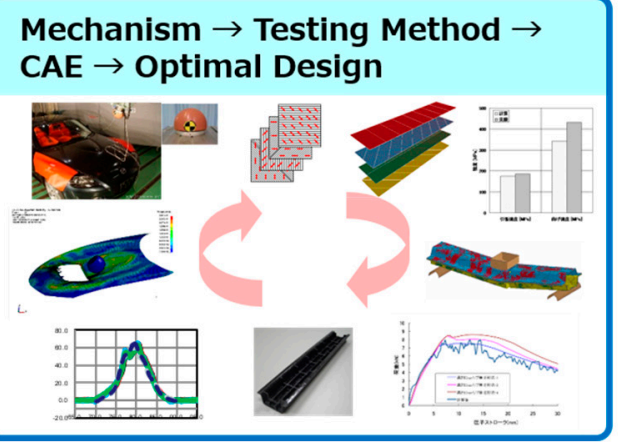

\section{Processing technology}

Multi-material and multi-molding solutions to meet the demand for structural properties and process cycle.
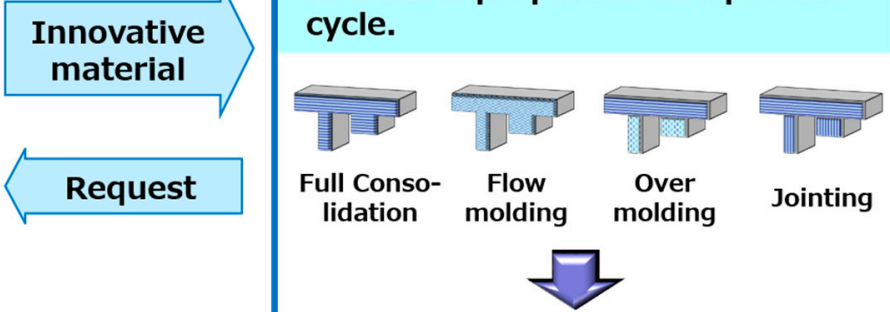

Innovation of equipment
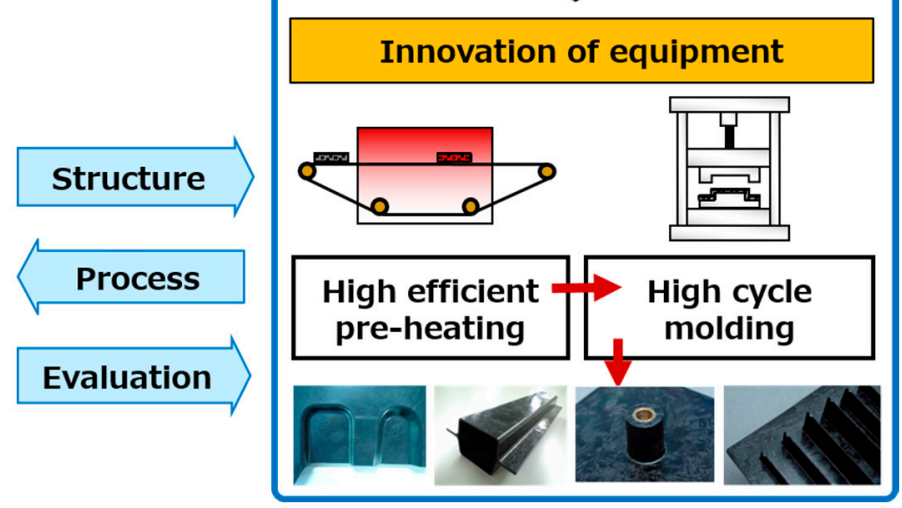

Figure 5. Research topics in the CFRTP projects.

Moreover, research focusing on mass-produced applications of CFRPs has also been conducted in other countries. Coordinated by Prof. Brian G. Falzon from Queen's University Belfast, UK, an EU project named ICONIC (Improving the Crashworthiness of Composite Transportation Structures) is in progress, which focuses on the crashworthiness behavior and the application solutions of CFRP for the transportation industry (aerospace, automotive, and rail industries). Meanwhile, two projects named FiBreMoD (Fibre Break Models for Designing novel composite microstructures and applications) and HyFiSyn (Hybrid Fibre-reinforced composites: achieving Synergetic effects through microstructural design and advanced simulation tools) coordinated by Prof. Yentl Swolfs from KU Leuven under funding support from the Marie Skłodowska-Curie Actions (MSCA) are also underway. The objective of these projects is to achieve a more sustainable society by enhancing the application feasibility of CFRPs as lightweight materials in different industrial fields. We believe that the research focusing on mass-produced applications of CFRPs will further increase in the near future. 


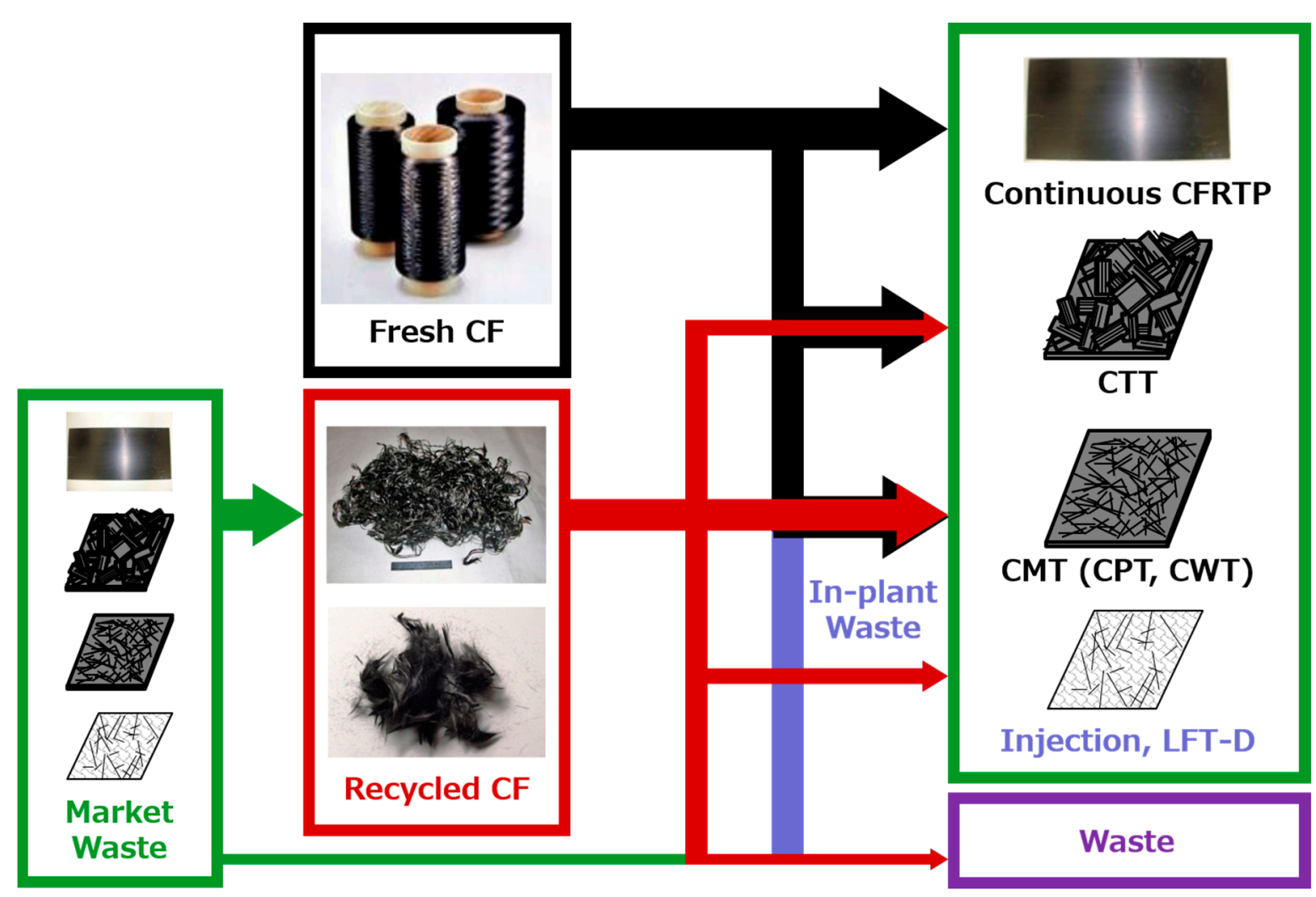

Figure 6. Intermediate materials and material flow developed in Japan's CFRTP projects: chopped carbon fiber tapereinforced thermoplastics (CTTs), carbon fiber mat-reinforced thermoplastics (CMTs), carbon fiber paper-reinforced thermoplastics (CPTs), and carbon fiber card web-reinforced thermoplastics (CWTs).

\subsection{High Performance of CFRTPs}

The thickness of the prepregs used in CTTs has a significant effect on the mechanical performance. Carefully designed random distribution processes can ensure the uniform dispersion. In Japan's CFRTP project, an ultra-thin prepreg is developed $(<50 \mu \mathrm{m})$, much thinner than conventional prepregs $(150 \mu \mathrm{m}$, in general). In addition, the tape distribution processes are designed to fabricate CTTs with small tapes $(5 \mathrm{~mm}$ in width and $20 \mathrm{~mm}$ in length) (Figure 7). As a result of the reduced thickness of the tape, the resin-impregnation speed is ten times faster than that of conventional products. Owing to the small dimensions of the tape, a low-cost papermaking technique can be applied for tape dispersion, which significantly decreases the manufacturing cost and time for both prepregs and components, showing an extremely high potential for applications in automotive mass production.

Additionally, the ultra-thin prepregs used in CTTs facilitate high-cycle molding processes and exhibit superior mechanical properties with low scatter (Figure 8). Studies show that mechanical properties depend on the tape length, and the maximum tensile and flexural mechanical properties of CTTs with a PA6 matrix exhibit similar performance to continuous CFRPs $[26,28,32,34]$. The effects of the tape morphology and fabrication process have also been studied in detail. The " $W$ " and " $\mathrm{D}$ " in Figure 9 denote "wet (papermaking) process" and "direct (bulk molding) process", respectively, and " $1 \mathrm{t}$ ", " $2 \mathrm{t}$ ", and " $3 \mathrm{t}$ " denote the thickness of the prepreg tapes. These results reveal that the mechanical properties significantly depend on both the tape thickness and fabrication process. More than a $30 \%$ increasing in the flexural modulus and over six times increasing in the coefficient of variation (CV) can be achieved by modifying the tape thickness and fabrication process [36]. Thus, the design of the fabrication process is of extreme importance for the mass production and application of the CTT. In particular, a finely designed process is required to ensure stable tape distribution and internal structures. Longer tapes and thinner prepregs can provide 
considerably improved mechanical properties, but both features decelerate the molding cycle (which directly affects the component cost). Hence, the mechanical performance, tape morphology, and fabrication process must be carefully considered based on the actual requirements of a given application.
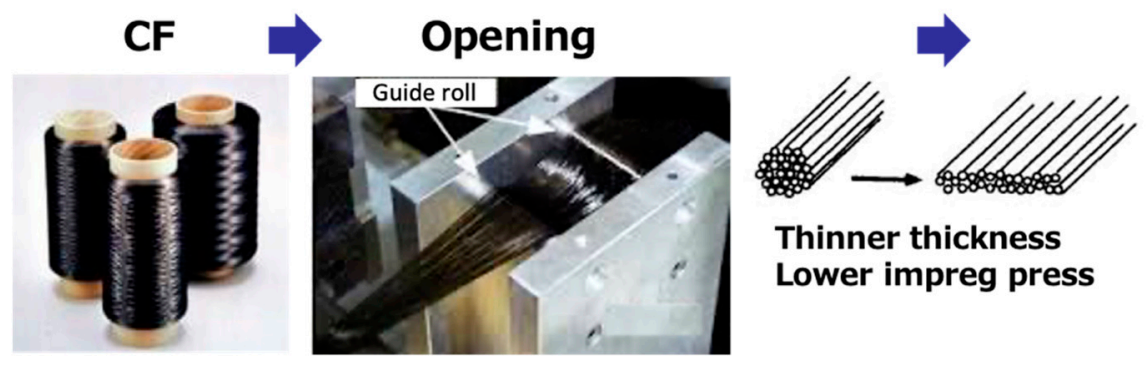

Thinner thickness

Lower impreg press
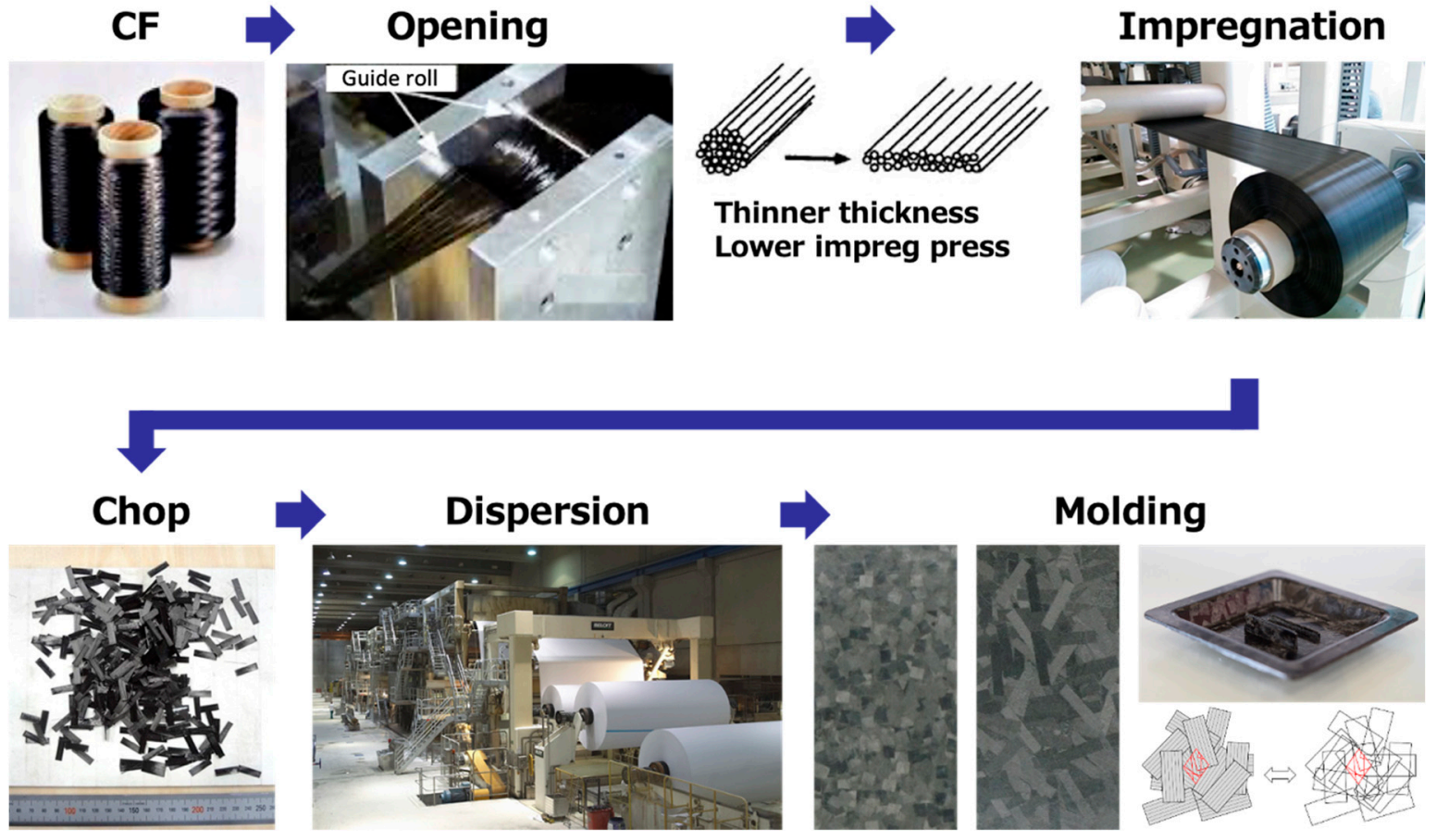

Figure 7. CTT fabrication process.

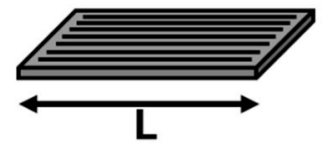

\section{CF Tape}

Thickness: $\mathrm{T}=\mathbf{0 . 0 4} \mathrm{mm}$

CF length: $L=n * 6 \mathrm{~mm}$

Aspect ratio: $\mathrm{R}=\mathrm{L} / \mathrm{T}$
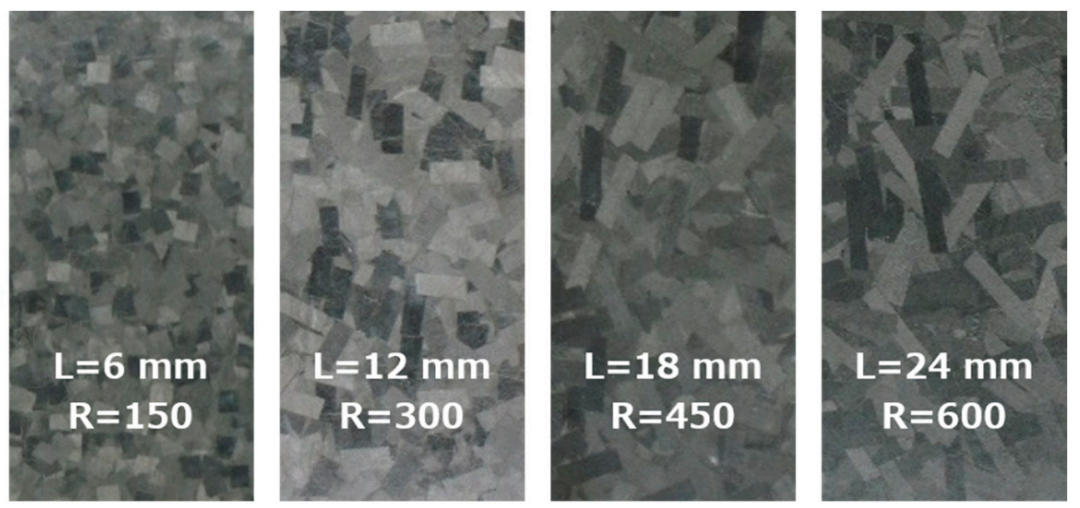

Tensile Modulus : 47 GPa

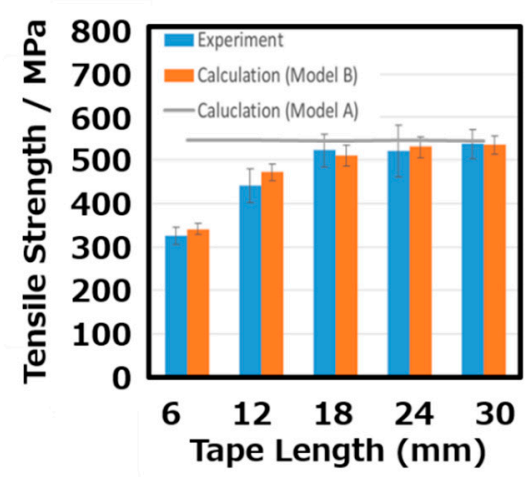

Flexural Modulus : $41 \mathrm{GPa}$

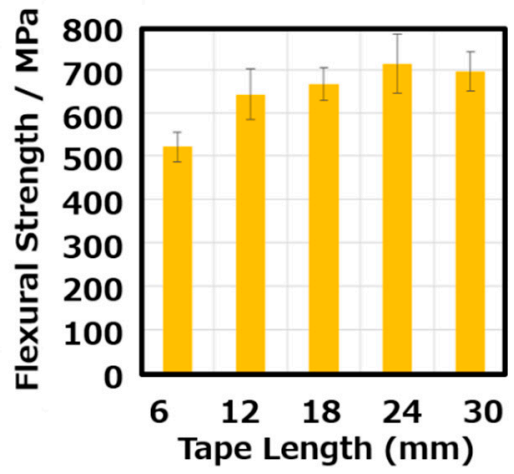

Figure 8. Dependence of the mechanical performance on the tape length: tensile and flexural strengths of ultra-thin CTTs. 


\begin{tabular}{|c|c|r|r|}
\hline & $\begin{array}{c}\text { Tape } \\
\text { thickness } \\
{[\mathrm{mm}]}\end{array}$ & $\begin{array}{c}\text { Flexural } \\
\text { Modulus } \\
{[\mathrm{GPa}]}\end{array}$ & \multicolumn{2}{|c|}{$\begin{array}{c}\text { CV } \\
{[\%]}\end{array}$} \\
\hline W1t & $\mathbf{0 . 0 4 4}$ & 43.0 & 3.9 \\
\hline W2t & 0.088 & 36.4 & 6.0 \\
\hline W3t & 0.132 & 34.1 & 10.5 \\
\hline D1t & 0.044 & 40.2 & 10.5 \\
\hline D2t & 0.088 & 33.9 & 18.7 \\
\hline D3t & 0.132 & 32.5 & 23.4 \\
\hline
\end{tabular}
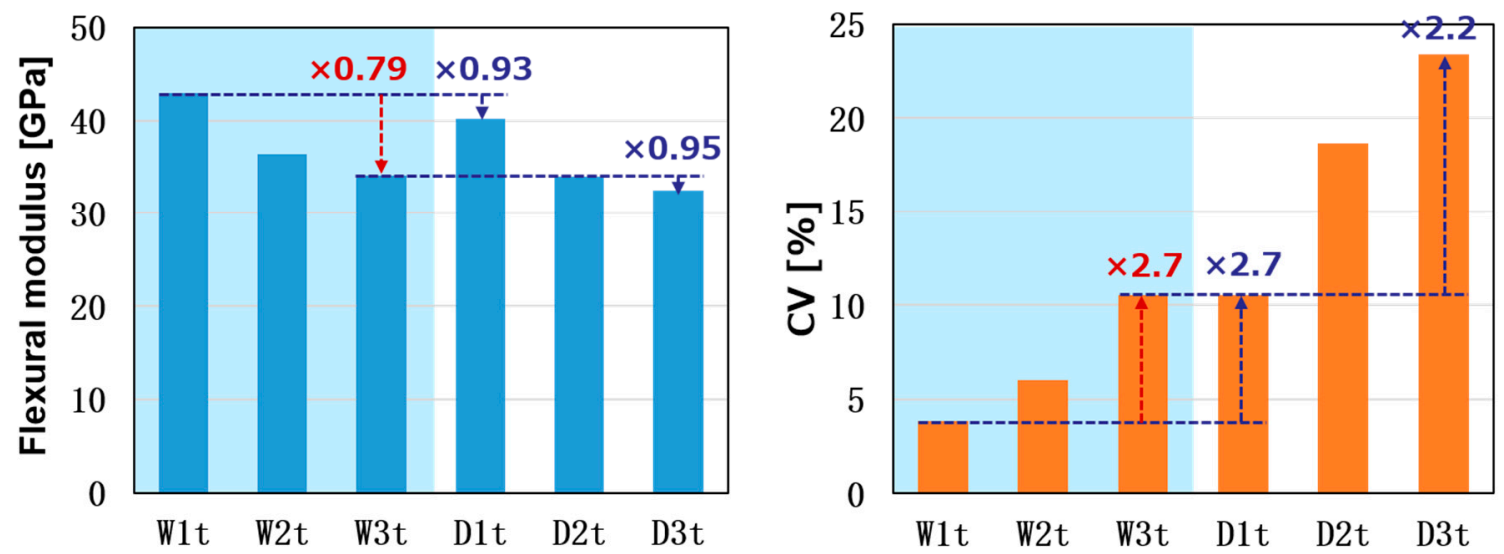

Figure 9. Effects of tape morphology and fabrication process on the mechanical properties of the CTT.

Compared to the conventional CFRTSs and discontinuous CFRTPs, CTTs have a remarkable and stable ability to absorb energy. Figure 10 illustrates bolt bearing test results, where the bearing load is constant at a higher level ( $80 \%$ of maximum load). The bearing strength is close to the tensile strength of the CTT with a $2 \% \mathrm{CV}$, providing the CTT with a high specific energy absorption feature $(300 \mathrm{~kJ} / \mathrm{kg})[30,39]$.

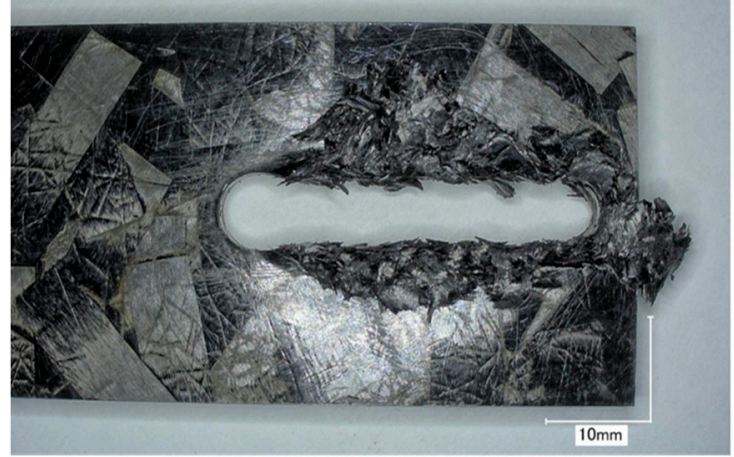

\begin{tabular}{cccc}
\hline reference & $\begin{array}{c}\text { Modulus } \\
{[\mathrm{GPa}]}\end{array}$ & $\begin{array}{c}\text { Strength } \\
{[\mathrm{MPa}]}\end{array}$ & $\begin{array}{c}\text { Failure } \\
\text { Strain [\%] }\end{array}$ \\
\hline $\begin{array}{c}\mathrm{CF} \\
(\mathrm{Vf}=55 \%)\end{array}$ & 240 & 4900 & 2.0 \\
\hline $\begin{array}{c}\mathrm{CTT} \\
\text { tensile }\end{array}$ & 49 & 520 & 1.1 \\
\hline $\begin{array}{c}\text { CTT } \\
\text { flexural }\end{array}$ & 42 & 700 & 1.7 \\
\hline
\end{tabular}

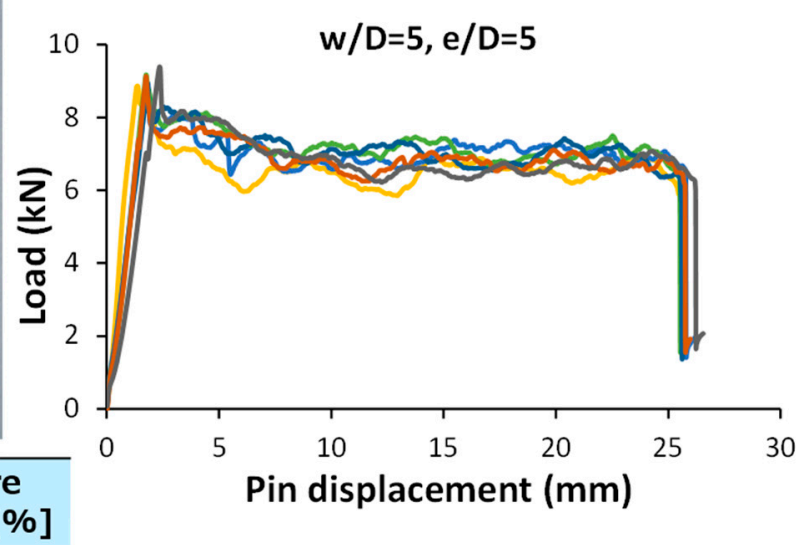

\begin{tabular}{ccc}
\hline $\begin{array}{c}\text { Bearing } \\
\text { strength } \\
\text { [MPa] }\end{array}$ & $\begin{array}{c}\text { CV } \\
{[\%]}\end{array}$ & $\begin{array}{c}\text { Energy } \\
\text { absorption } \\
\text { [kJ/kg] }\end{array}$ \\
\hline 473 & 2.18 & 300 \\
\hline
\end{tabular}

Figure 10. Bolt bearing and energy absorption properties of CTTs. 
The internal geometry evaluation using micro-computerized X-ray tomography $(\mu-\mathrm{CT})$ and simulation modeling of the CTT provided more detailed material features pertaining to its mass production in the automotive industry. Such $\mu$-CT methods provide a strong capability for visualization and quantification of multiscale fiber orientation distributions, tape morphologies, 3D internal structures, and orientation misalignments [60,61]. Moreover, the internal geometry defects (e.g., tape splitting and out-of-plane tape waviness) can be visualized using the $\mu-\mathrm{CT}$ methodologies (Figure 11). The fiber orientation distribution information acquired from $\mu-\mathrm{CT}$ is used to model CTTs for the prediction of mechanical properties, considering the internal geometry features (Figure 12). An equivalent square ply model based on the classical laminate theory and Monte-Carlo simulations can together predict the average and CV value of the CTT with different tape morphologies. This can clarify the relationship between the mechanical stochastic properties and internal geometries [25,36]. The modified Mori-Tanaka homogenization model was also established to calculate the mechanical properties with a given fiber orientation distribution and tape size $[27,33,40]$. The "de-homogenization" model (also known as the equivalent laminate model) considers a CTT as an equivalent laminate with specified defect factors (out-ofplane tape waviness, for example) [40]. The de-homogenization model can accurately predict strength owing to the careful consideration of the internal structural defects.

The CTTs fabricated using ultra-thin tapes with small dimensions have demonstrated outstanding mechanical performance, high-cycle moldability, and designability for automotive industry applications. Although the cost of CTTs can be reduced by shortening the molding cycle time, affordability remains the main issue for mass-production applications. Consequently, additional solutions must be found to achieve the goal of mass application in automotive industry.

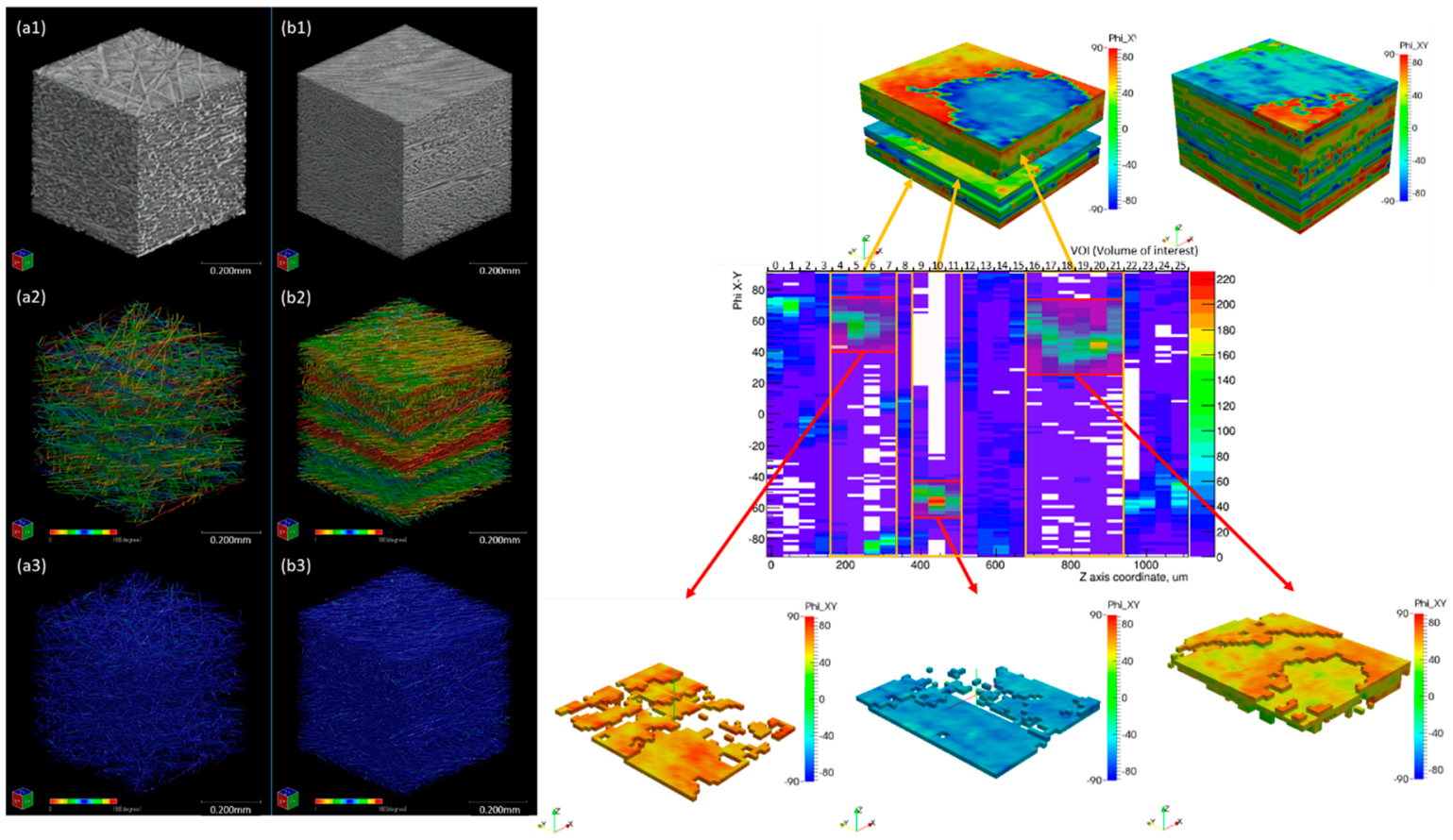

Figure 11. $\mu$-CT methodologies for the study of the internal geometry of CTTs $[33,60]$. 


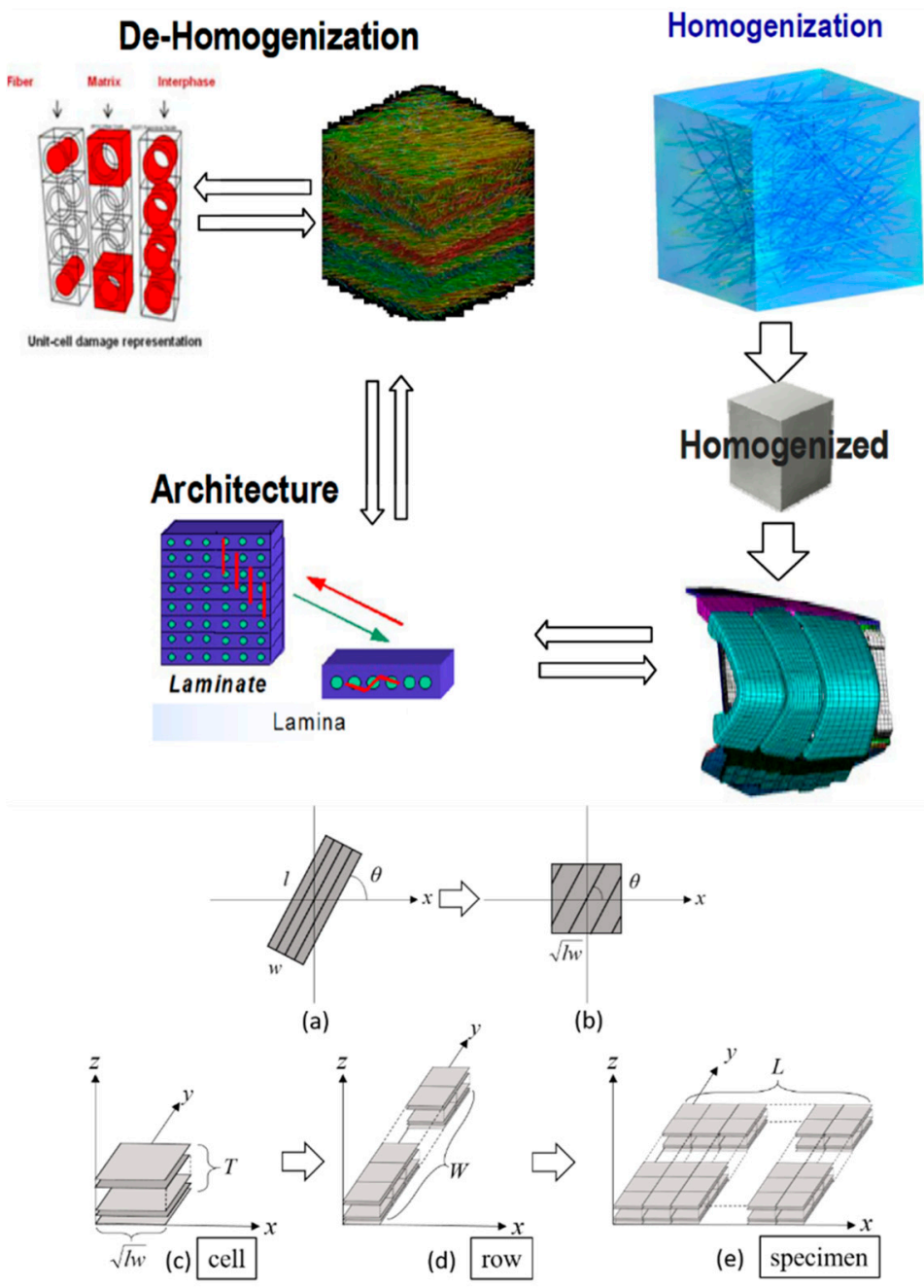

Figure 12. Mechanical modeling of CTT $[25,40]$.

\subsection{Functionality and Recyclability of CFRTP}

Although a CTT combining high performance and high-cycle molding time was developed, the cost challenge remains an important obstacle towards the mass-production application in the automotive industry. Consequently, functional CFRTPs and recycling technologies were developed.

Apart from high-performance CTTs, CWTs and CPTs were developed for functionality, which primarily differ in their fabricating processes and fiber length. CWTs are fabricated using a carding machine, and the carbon fiber used for CWTs must be tens of millimeters in length to ensure a proper carding process, as well as beneficial mechanical performance. In contrast, CPTs are fabricated using the papermaking method, and the carbon fiber length is fixed at $6 \mathrm{~mm}$, which is significantly shorter than that of CWTs (Figure 13). The mechanical properties of CWTs are significantly better than those of CPTs and comparable to those of CTTs after the stretching process. This process is an optional fabrication postprocess (Figure 14) that aims to enhance the in-plane orientation preference generated during the carding process. Based on the object-oriented structure optimization, the effective utilization of this strong in-plane anisotropy can provide a more flexible option for applications [56,59]. 


\begin{tabular}{|c|c|l|l|l|}
\hline & Matrix & \multicolumn{1}{|c|}{ CF Length } & \multicolumn{1}{|c|}{ Process } & \multicolumn{1}{|c|}{ Advantage } \\
\cline { 1 - 3 } CTT & & As you wish & Confidential & $\begin{array}{l}\text { High Vf and } \\
\text { energy absorption }\end{array}$ \\
\cline { 4 - 5 } $\begin{array}{c}\text { CMT } \\
\text { (CWT) }\end{array}$ & \multirow{2}{*}{$\begin{array}{l}\text { PA } \\
\text { PP }\end{array}$} & $\begin{array}{l}\text { Widely } \\
\text { distributed up } \\
\text { to several cm }\end{array}$ & $\begin{array}{l}\text { Carding } \\
\text { Machine }\end{array}$ & Very productive \\
\cline { 4 - 5 } $\begin{array}{c}\text { CMT } \\
\text { (CPT) }\end{array}$ & & $\begin{array}{l}\text { Concentrated } \\
\text { around 6 } \mathrm{mm}\end{array}$ & $\begin{array}{l}\text { Paper } \\
\text { Making } \\
\text { Method }\end{array}$ & $\begin{array}{l}\text { Short fiber } \\
\text { can be used } \\
\text { Small scatter }\end{array}$ \\
\hline
\end{tabular}

CTT: Carbon Fiber Tape Reinforced Thermoplastics CMT: Carbon Fiber Mat Reinforced Thermoplastics CWT: Carbon Fiber Card Web Reinforced Thermoplastics CPT: Carbon Fiber Paper Reinforced Thermoplastics
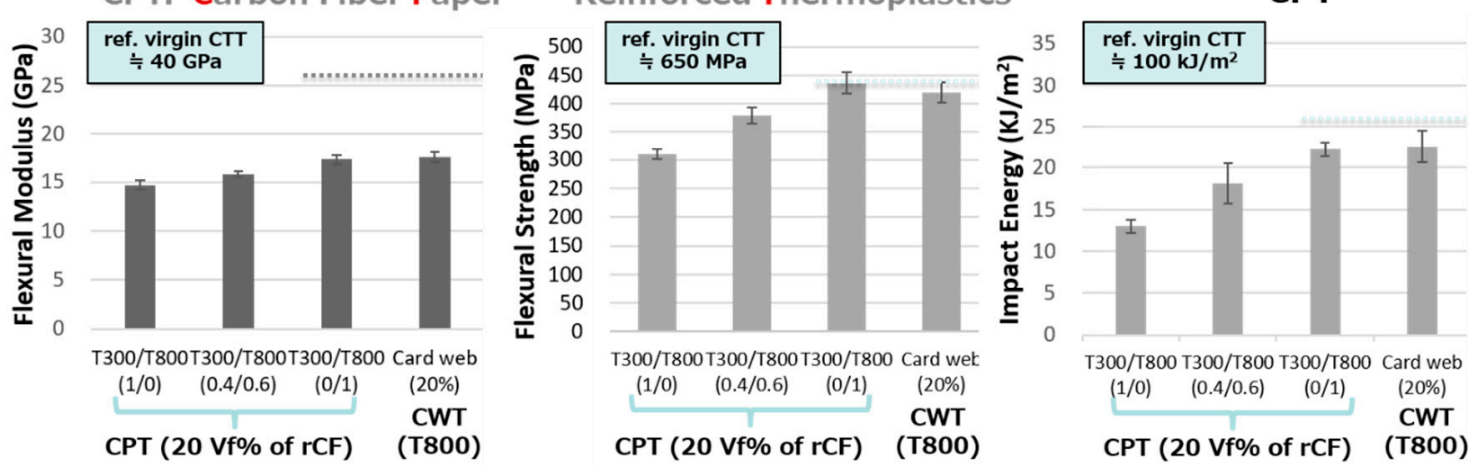

Figure 13. Fabrication and mechanical properties of CTTs, CWTs, and CPTs.

The internal structure of the non-woven mat endows CWTs and CPTs with specialized functionality. In particular, a feature named "spring-back" has been demonstrated (Figure 15) [41-43]. The fibers are elastically deformed in CMTs because of the fiber bridging effect. After heating, this elastic deformation is released, and the internal structure springs back in the out-of-plane direction. The spring-back of CMTs generate an ultra-light CFRTP lattice structure, which shows considerable mechanical performance while being extraordinarily lightweight. CFRTP sandwich components have been developed with the spring-back CMTs as the core material $[45,46,57]$. This sandwich material is lighter than water $\left(\rho \sim 0.85 \mathrm{~g} / \mathrm{cm}^{3}\right)$ and has higher toughness than traditional CFRPs (Figure 15). Moreover, toughening hybridization can be easily applied during the carding and papermaking processes [48-50]. Figure 16 illustrates a CPT hydride toughened with aramid fiber paper, which may significantly improve the toughness. Consequently, CMTs can be applied in components where the toughness is more important than the strength and stiffness. Furthermore, a multi-material solution can reduce the lifecycle cost of the CFRTP automotive applications. In addition, a soft skin effect, which contributes to pedestrian safety, and higher residual mechanical properties after lightning strikes have proven to be attractive features, both of which are due to the matrix resin ductility [62]. Additionally, heat/sound insulation properties of the spring-back lattice structure have been investigated, such as applications of CPTs.

Concerns have been raised regarding the degradation of recycled carbon fiber during the resin removal process and the regeneration of functional groups for thermoplastics adhesion to remake CFRTPs. Several recycling technologies have been developed for recycling the carbon fiber from CFRP parts (Table 1). The superheated steam treatment method was selected because it can sensitively control carbon fiber degradation and add functional groups simultaneously while maintaining a low cost (Figure 17) [63-67]. Additionally, the CWT fabrication process can tolerate a wider range of carbon fiber lengths, which can be beneficial as the lengths of the recycled carbon fibers often have a wide distribution [53-56,59]. The CWTs fabricated with the post-carding stretching process have strong in-plane anisotropic mechanical properties, which can serve as intermediate 
materials to fabricate high-performance CFRTPs with length-scattered recycled carbon fiber (Figures 13 and 14) [56,59].

The combination of the high performance of CTTs with the functional and recycling efficiency of CMTs provide a multi-material solution that can fulfill the high-cycle mass production and low-cost requirements. This solution has also demonstrated feasibility for mass production in automotive applications.

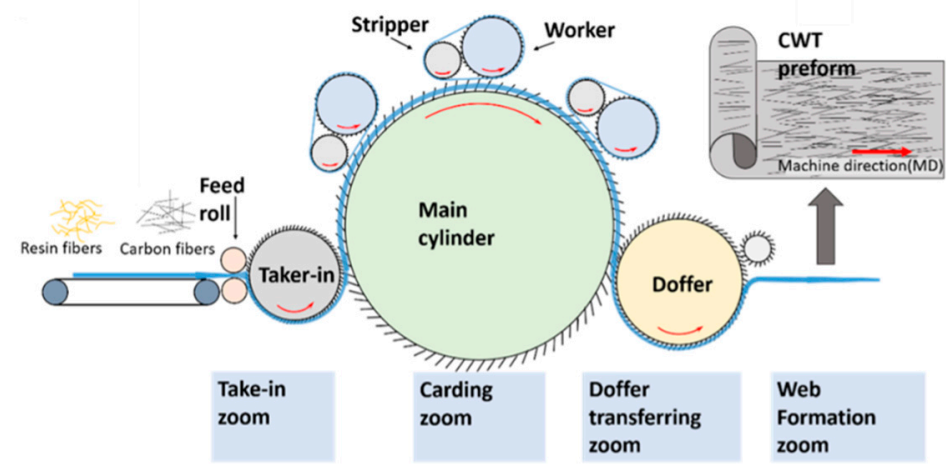

Carding process

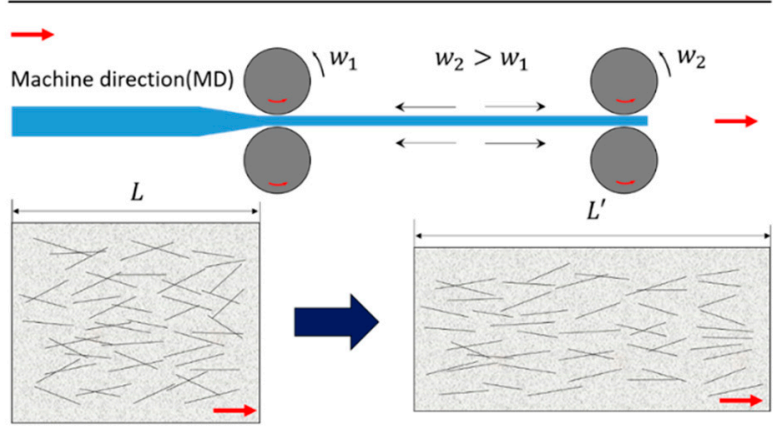

Stretching process

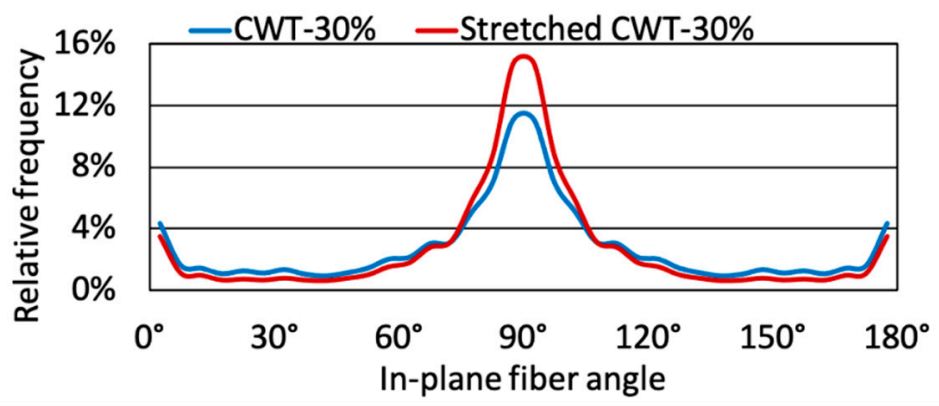

Figure 14. Carding process, stretching process, and the in-plane fiber orientation distribution of CWT with/without stretching. 

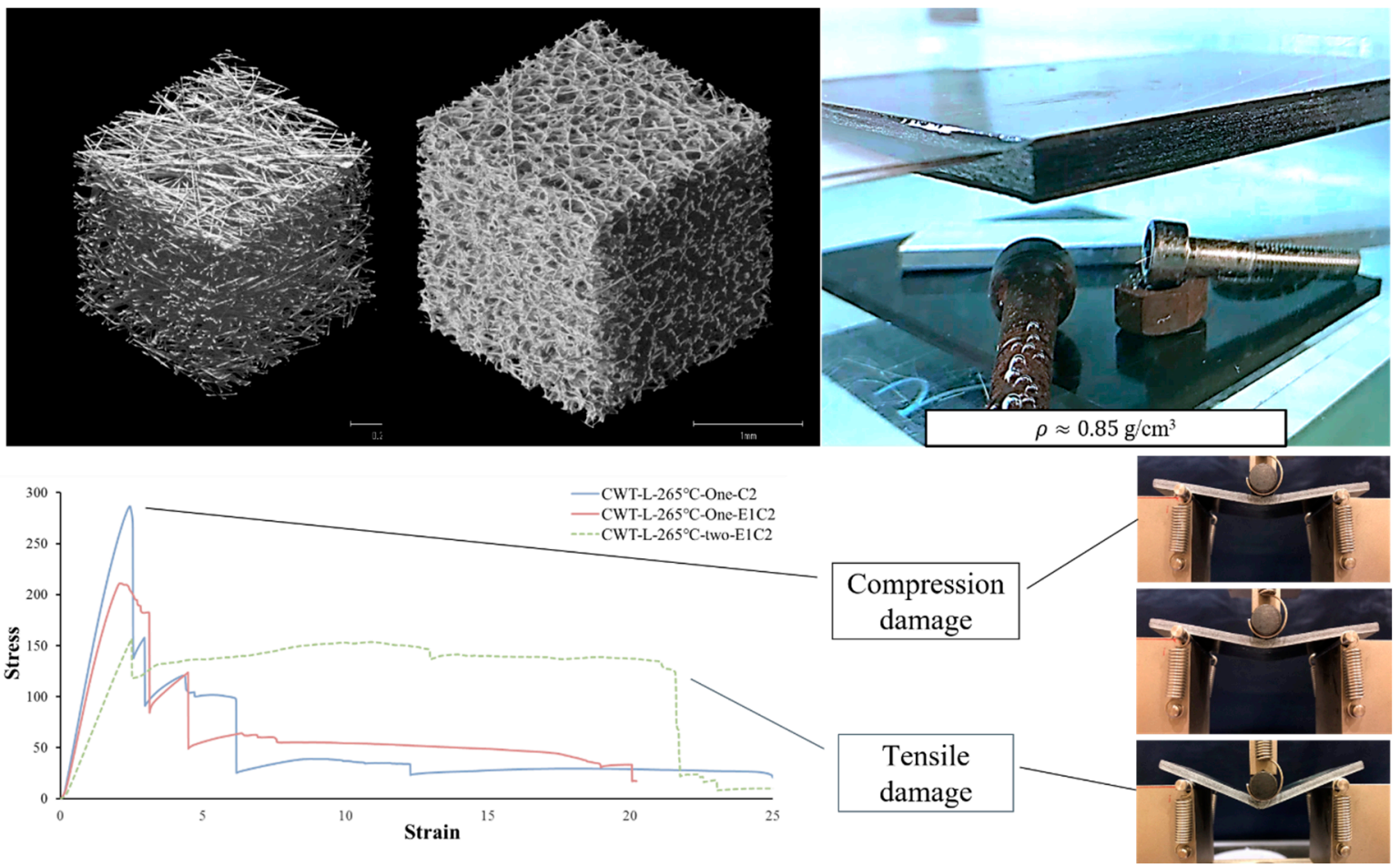

Figure 15. Spring-back effect and the toughened spring-back sandwich fabricated from CWTs.

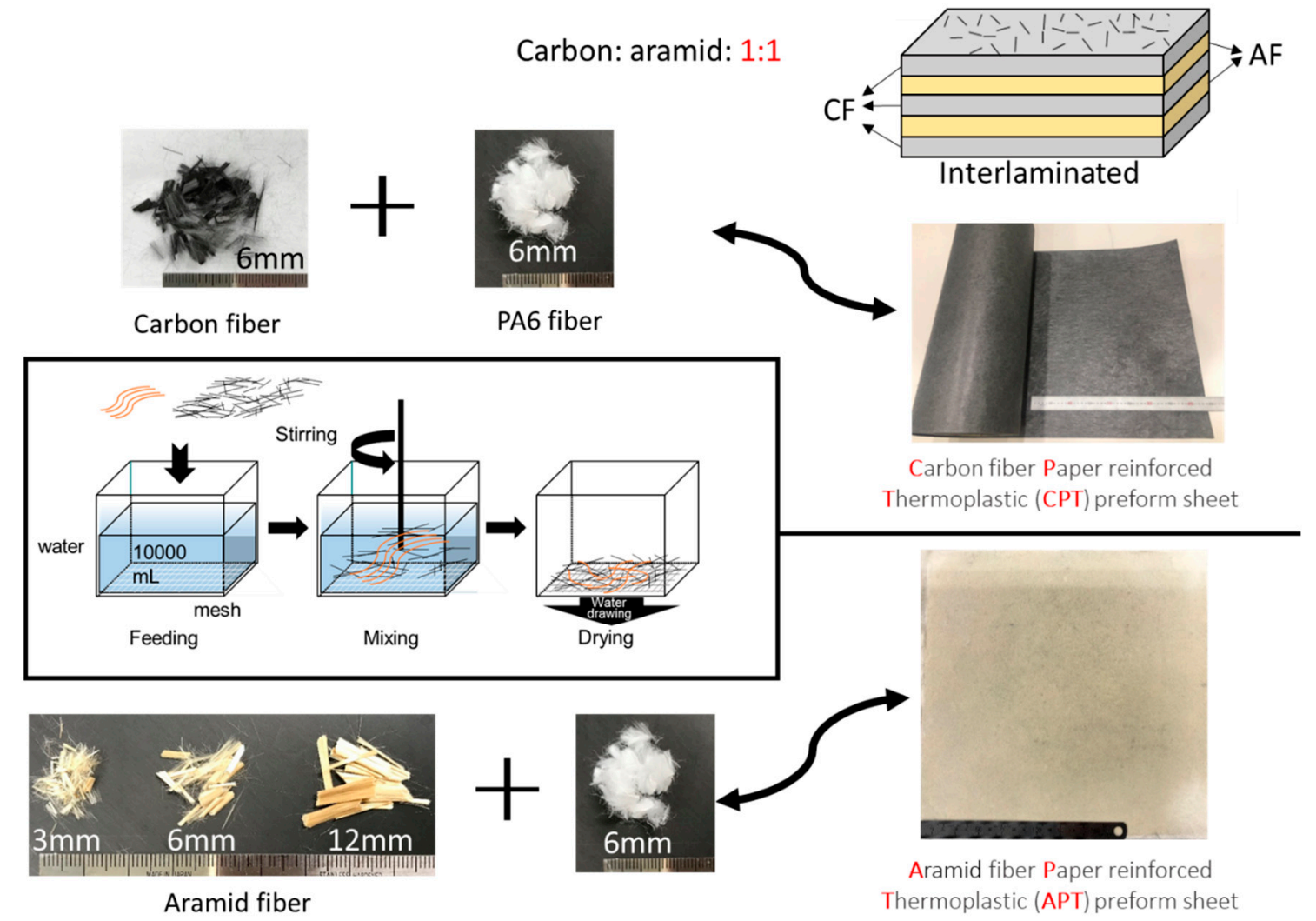

Figure 16. Diagram showing the features of CPT sandwich hydride toughened with aramid fiber paper. 
Table 1. Methods for CFRP recycling.

\begin{tabular}{|c|c|c|c|c|}
\hline & Pyrolysis & $\begin{array}{c}\text { Superheated Steam } \\
\text { Treatment }\end{array}$ & Depolymerization & $\begin{array}{c}\text { Subcritical/Supercritical } \\
\text { Fluid }\end{array}$ \\
\hline Temperature $/{ }^{\circ} \mathrm{C}$ & $500-700$ & $500-700$ & $100-200$ & $250-400$ \\
\hline Pressure/MPa & 0.1 & 0.1 & 0.1 & $1-25$ \\
\hline Other Conditions & Air, $\mathrm{N}_{2}$ & $\begin{array}{c}\text { Steam } \\
+ \\
\text { Surface treatment } \\
\text { Gas }\left(\mathrm{N}_{2}, \mathrm{CO}_{2}, \mathrm{H}_{2}\right)\end{array}$ & $\begin{array}{c}\text { Solvent: } \\
\text { Benzyl Alcohol } \\
\text { Catalyst: } \\
\text { Tripotassium Phosphate }\end{array}$ & $\begin{array}{c}\text { Solvent: } \\
\text { Alcohol, Acetone, Water } \\
\text { Catalyst (subcritical): } \\
\text { Alkaline Metals }\end{array}$ \\
\hline Feature & $\begin{array}{l}\text { Air: CF degradation } \\
\text { N2: High cost, } \\
\text { resin residue }\end{array}$ & $\begin{array}{l}\text { Functionalization is } \\
\text { possible }\end{array}$ & $\begin{array}{c}\text { Low cost } \\
\text { Functional groups remain } \\
\text { Applicable resin is restricted } \\
\text { (ex. PP is not applicable) }\end{array}$ & $\begin{array}{l}\text { High investment } \\
\text { Low processing } \\
\text { efficiency }\end{array}$ \\
\hline
\end{tabular}

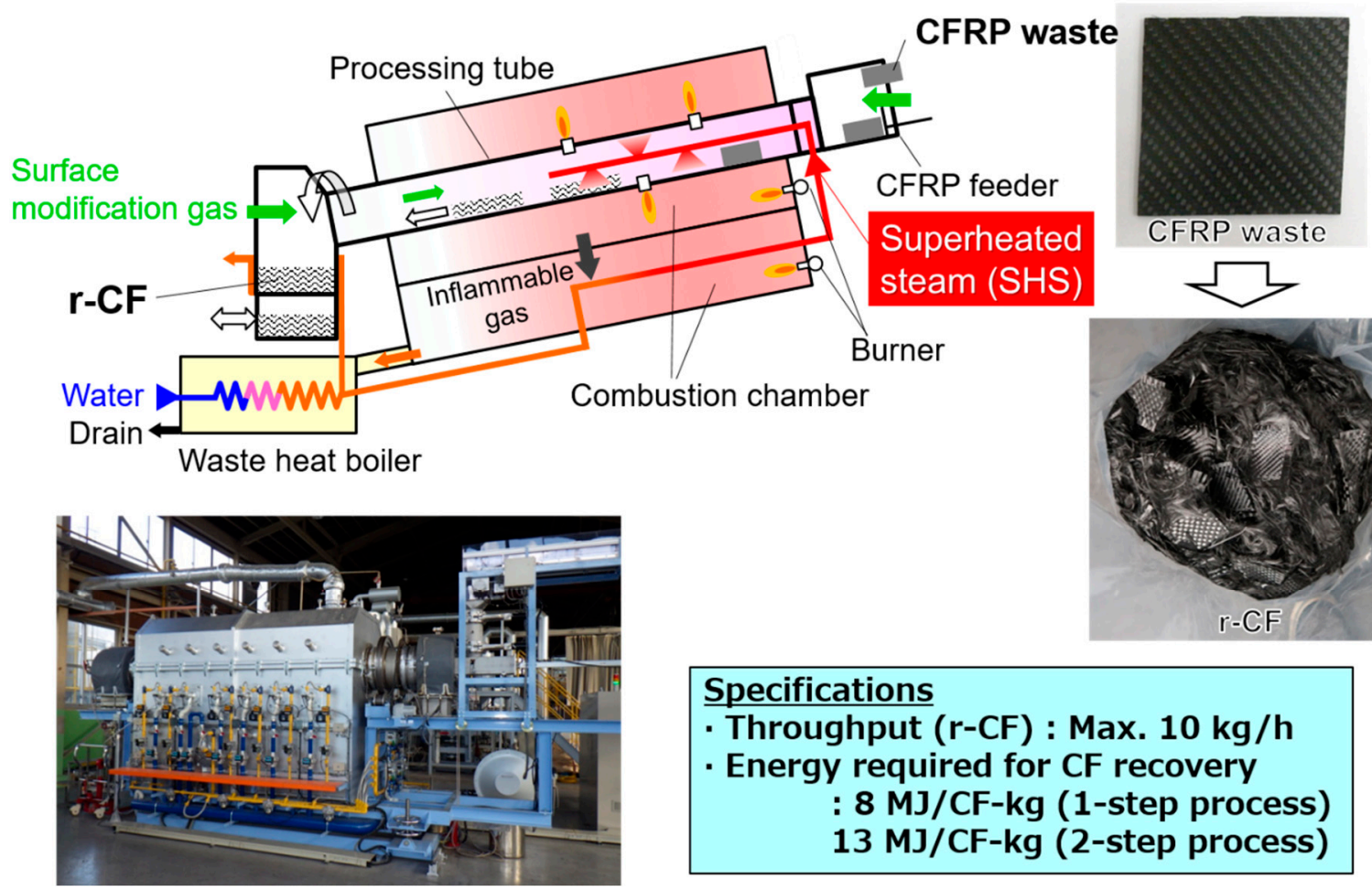

Figure 17. Superheated steam treatment process for recycling carbon fiber from CFRP parts.

\subsection{Future of CFRTPs in Automotive Applications}

To promote the use of CFRTPs in mass-production applications in the automotive industry, not only is a feasible material solution required but also a life cycle assessment that can predict the development and consumption tendency of carbon fiber and components usage.

Currently, approximately $60 \%$ of virgin carbon fiber remains in automotive CFRP parts during fabrication and the remaining fiber is wasted. However, if the discontinuous CFRTPs and their fabrication processes are introduced, over $90 \%$ of virgin carbon fiber can be incorporated into the automotive CFRP parts, according to the prediction (Figure 18. Moreover, with the popularization of CFRP recycling technologies, the recycled CFRPs show much lower energy requirement compared to those using virgin fiber (Figure 19). The manufacturing of carbon fiber consumes high energy, but the energy consumed in the recycling and high-cycle molding processes can be less than that used for making steel. 
Consequently, the energy intensity of recycled CFRTPs can be lower than that of recycled steel, which will also be advantageous to the automotive industry.

\section{【150 kg of Fresh CF】}

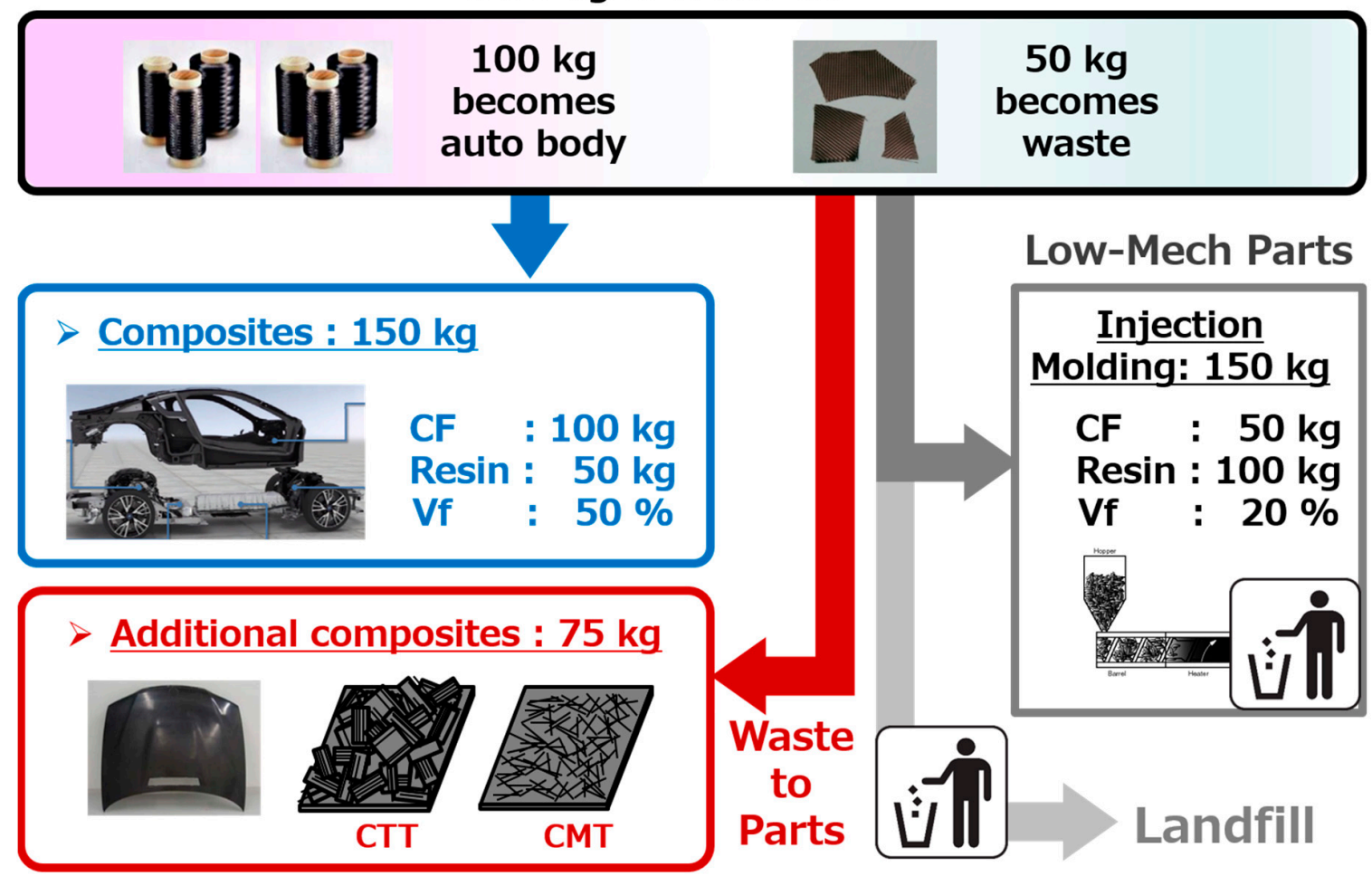

Figure 18. Fabrication processes for automotive CFRP parts with discontinuous CFRTPs.

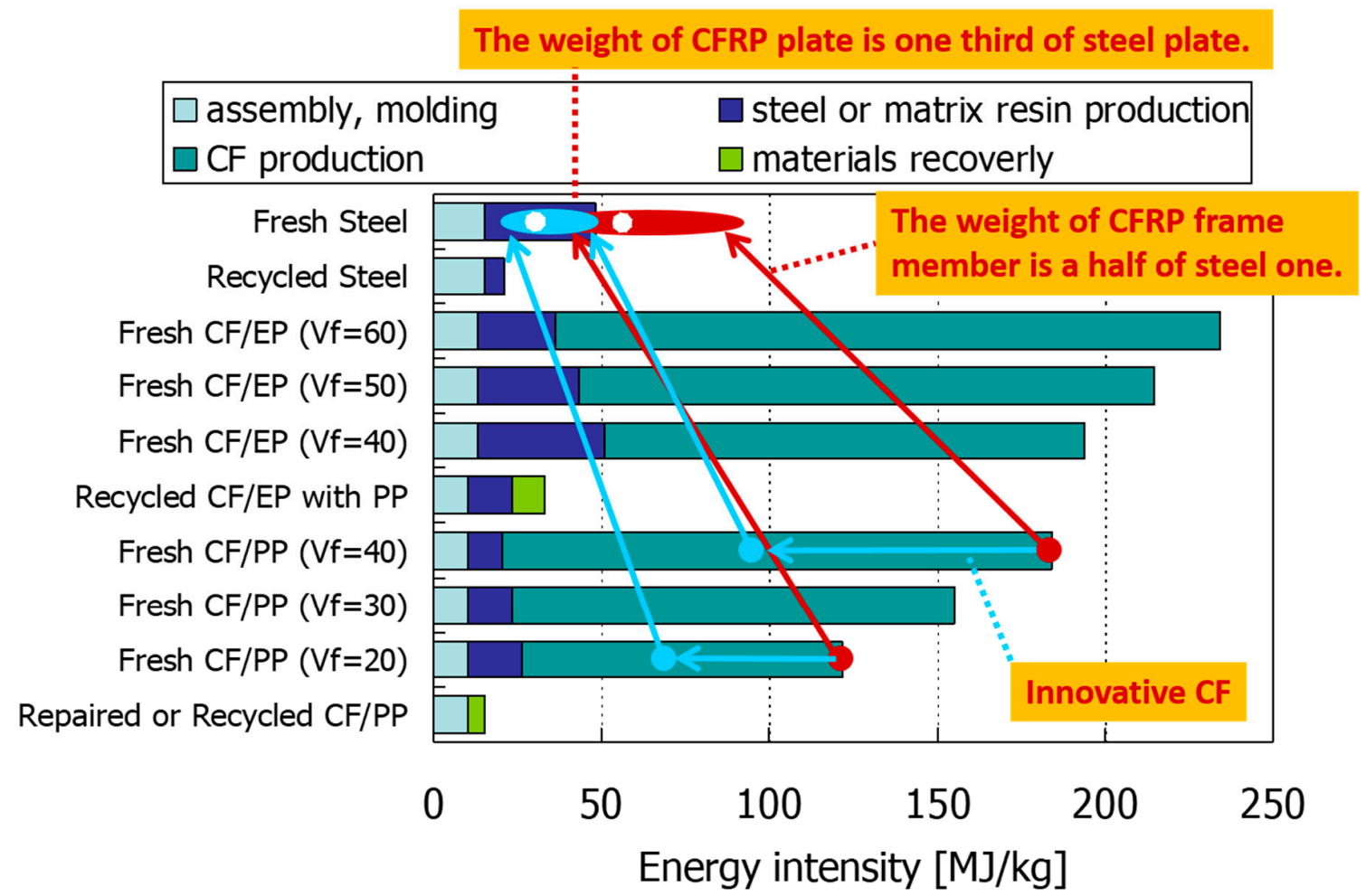

Figure 19. Energy intensities of fresh and recycled steel, CF/epoxy composite, and CF/polypropylene (PP) composite. 
The automotive industries have started showing considerable interest in the mass production of specialized CFRTPs, CFRP recycling technologies, and the feasibility of lowcost CFRTP fabrication. However, the vastly different magnitude in productivity hinders the successful application of CFRTPs in automotive mass production, compared to the conventional applications, such as motorsports and supercars, which are produced at a smaller scale. A small improvement in the design can result in huge benefits; therefore, the development flow of CFRTPs for automotive mass production (Figure 20) should be carried out meticulously. Moreover, the structure optimization based on the loading conditions on components rather than traditional material replacement should be emphasized to take full advantage of the anisotropic features of CFRTPs [68-78]. Repair capability, non-destructive evaluation, environmental tolerance, and flexible multi-material solution are also important for the adoption of CFRTP-based materials in the automotive industry [79-89].

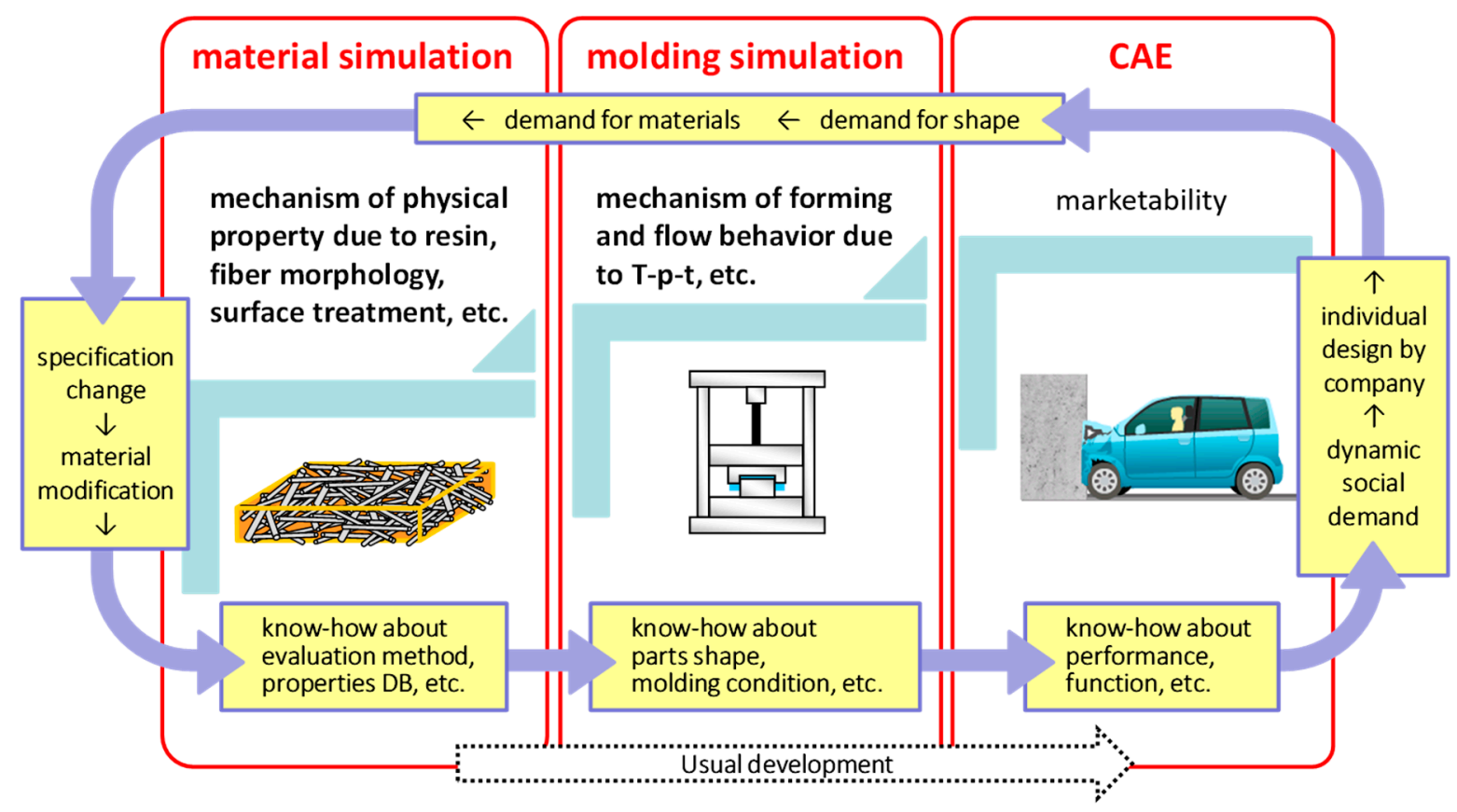

Figure 20. Development flow of CFRTPs for automotive mass production.

\section{Conclusions}

The application of CFRTPs in automotive mass production has garnered increasing attention from researchers and engineers in related fields. The systematic development of lightweight CFRTP applications suitable for mass production in the automotive industry has been introduced herein. The demand for its development has arisen from current environmental issues and increasing worldwide regulations regarding $\mathrm{CO}_{2}$ emissions. Further, the high potential for weight reduction in mass production has accelerated the development of CFRTPs. The specific requirements of CFRTPs for lightweight applications and the current development status and basic scientific outputs have also been presented, and the importance of object-oriented material development has been emphasized. The fabrication processes of CFRTPs designed with the trade-off between cost and performance shows feasibility for accomplishing the application target. The optimal structure design for functional CMTs provides flexible options for applications. The recycling and usage flow of the carbon fibers and CFRTPs have been evaluated using a cost sensitivity analysis to ensure feasibility and affordability in automotive mass production applications. The authors hope this article can provide references and valuable discussion for researchers and engineers to enable the use of CFRTPs in lightweight automotive applications. 
Author Contributions: Conceptualization, Y.W. and J.T.; methodology, Y.W. and J.T.; validation, Y.W. and J.T.; formal analysis, Y.W. and J.T.; investigation, Y.W. and J.T.; data curation, Y.W. and J.T.; writing—original draft preparation, Y.W.; writing—review and editing, Y.W. and J.T.; visualization, Y.W. and J.T.; supervision, J.T.; project administration, J.T.; funding acquisition, J.T. All authors have read and agreed to the published version of the manuscript.

Funding: This research received no external funding.

Informed Consent Statement: Informed consent was obtained from all subjects involved in the study.

Data Availability Statement: No new data were created or analyzed in this study. Data sharing is not applicable to this article.

Acknowledgments: This study was conducted as the Japanese METI project "the Future Pioneering Projects/Innovative Structural Materials Project" since the financial year 2013. The authors would like to express their sincere appreciation to the project members who have provided valuable information and useful discussions.

Conflicts of Interest: The authors declare no conflict of interest.

\section{References}

1. Henry, A. McLaren: Formula 1 Racing Team; Haynes: Sparkford, Somerset, 1999.

2. Takahashi, J. Energy Saving Strategy in Transportation by using CFRP. In Proceedings of the Automotive Forum in JEC Paris, Paris, France, 3-5 March 2010.

3. Takahashi, J. Strategies and technological challenges for realizing lightweight mass production automobile by using thermoplastic CFRP. In Proceedings of the Innovative Composites Summit on JEC Asia, Singapore, Singapore, 29 August 2011.

4. Ishikawa, T.; Amaoka, K.; Masubuchi, Y.; Yamamoto, T.; Yamanaka, A.; Arai, M.; Takahashi, J. Overview of automotive structural composites technology developments in Japan. Compos. Sci. Technol. 2018, 155, 221-246. [CrossRef]

5. Takahashi, J. Expectations and challenge of thermoplastic CFRP. In Proceedings of the SAMPE Japan Symposium “Future of Automobile Pioneered by Advanced Materials", Tokyo, Japan, 2-6 September 2016.

6. Balakrishnan, V.S.; Seidlitz, H. Potential repair techniques for automotive composites: A review. Compos. Part B Eng. 2018, 145, 28-38. [CrossRef]

7. Kizaki, T.; Zhang, J.W.; Yao, Q.Y.; Yanagimoto, J. Continuous manufacturing of CFRP sheets by rolling for rapid fabrication of long CFRP products. Compos. Part B Eng. 2020, 189, 10. [CrossRef]

8. Yao, S.S.; Jin, F.L.; Rhee, K.Y.; Hui, D.; Park, S.J. Recent advances in carbon-fiber-reinforced thermoplastic composites: A review. Compos. Part B Eng. 2018, 142, 241-250. [CrossRef]

9. Feraboli, P.; Peitso, E.; Cleveland, T.; Stickler, P.B. Modulus Measurement for Prepreg-based Discontinuous Carbon Fiber/Epoxy Systems. J. Compos. Mater. 2009, 43, 1947-1965. [CrossRef]

10. Feraboli, P.; Peitso, E.; Deleo, F.; Cleveland, T.; Stickler, P.B. Characterization of Prepreg-Based Discontinuous Carbon Fiber/Epoxy Systems. J. Reinf. Plast. Compos. 2009, 28, 1191-1214. [CrossRef]

11. Feraboli, P.; Cleveland, T.; Ciccu, M.; Stickler, P.; DeOto, L. Defect and damage analysis of advanced discontinuous carbon/epoxy Composite Materials. Compos. Part A Appl. Sci. Manuf. 2010, 41, 888-901. [CrossRef]

12. Feraboli, P.; Cleveland, T.; Stickler, P.; Halpin, J. Stochastic laminate analogy for simulating the variability in modulus of discontinuous Composite Materials. Compos. Part A Appl. Sci. Manuf. 2010, 41, 557-570. [CrossRef]

13. Selezneva, M.; Lessard, L. Characterization of mechanical properties of randomly oriented strand thermoplastic composites. $J$. Compos. Mater. 2016, 50, 2833-2851. [CrossRef]

14. Selezneva, M.; Roy, S.; Meldrum, S.; Lessard, L.; Yousefpour, A. Modelling of mechanical properties of randomly oriented strand thermoplastic composites. J. Compos. Mater. 2017, 51, 831-845. [CrossRef]

15. Visweswaraiah, S.B.; Selezneva, M.; Lessard, L.; Hubert, P. Mechanical characterisation and modelling of randomly oriented strand architecture and their hybrids-A general review. J. Reinf. Plast. Compos. 2018, 37, 548-580. [CrossRef]

16. Li, Y.Z.; Pimenta, S.; Singgih, J.; Nothdurfter, S.; Schuffenhauer, K. Experimental investigation of randomly-oriented tow-based discontinuous composites and their equivalent laminates. Compos. Part A Appl. Sci. Manuf. 2017, 102, 64-75. [CrossRef]

17. Karakaya, N.; Papila, M.; Ozkoc, G. Overmolded hybrid composites of polyamide-6 on continuous carbon and glass fiber/epoxy composites: 'An assessment of the interface'. Compos. Part A Appl. Sci. Manuf. 2020, 131, 105771. [CrossRef]

18. Kasemphaibulsuk, P.; Holzner, M.; Kuboki, T.; Hrymak, A. Foam injection molding of glass fiber reinforced polypropylene composites with laminate skins. Polym. Compos. 2018, 39, 4322-4332. [CrossRef]

19. Carello, M.; Amirth, N.; Airale, A.G.; Monti, M.; Romeo, A. Building Block Approach' for Structural Analysis of Thermoplastic Composite Components for Automotive Applications. Appl. Compos. Mater. 2017, 24, 1309-1320. [CrossRef]

20. Hartley, W.D.; McCann, J.; Davis, S.; Hocker, T.; Bobba, S.; Verghese, N.; Bajaj, D.; Yu, H.Z.; Dillard, D.A. Fracture Characterization of Overmold Composite Adhesion. J. Thermoplast. Compos. 2020. [CrossRef]

21. Takahashi, J. Development of innovative CFRTP technologies for mass-produced cars. JEC Compos. Mag. 2013, 81, 44-45. 
22. Takahashi, J.; Fujita, M.; Wan, Y. Toward a new generations of composites for our common future-Some activities on CFRTP for automotive applications. In Proceedings of the 15th European-Japanese Meeting on Composite Materials, London, UK, 25-26 September 2017.

23. Takahashi, J.; Ishikawa, T. Current Japanese Activity in CFRTP for Automotive Application. In Proceedings of the 13th EuroJapanese Symposium on Composite Materials, Nantes, France, 4-6 November 2013.

24. Takahashi, J.; Ishikawa, T. Next challenge in CFRTP for mass production automotive application. In Proceedings of the SEICO 14 SAMPE EUROPE 35th International Conference and Forum, Paris, France, 11 March 2014.

25. Sato, Y.; Takahashi, J.; Matsuo, T.; Ohsawa, I.; Kiriyama, K.; Nago, S. Elastic modulus estimation of chopped carbon fiber tape reinforced thermoplastics using the monte carlo simulation. In Proceedings of the 19th international Conference on Composite Materials, Montréal, QC, Canada, 28 July-2 August 2013; pp. 6718-6725.

26. Wan, Y.; Takahashi, J. Fiber Length Effect On Tensile And Compressive Strength Of Short Fiber Reinforced Thermoplastics. In Proceedings of the 16th European Conference On Composite Materials, Seville, Spain, 22-26 June 2014.

27. Wan, Y.; Ohori, T.; Takahashi, J. Mechanical properties and modeling of discontinuous carbon fiber reinforced thermoplastics. In Proceedings of the 20th International Conference on Composite Materials, Copenhagen, Denmark, 19-24 July 2015; pp. 3222-3224.

28. Wan, Y.; Takahashi, J. Effect of tape length and impregnation conditions on mechanical properties of carbon fiber tape reinforced thermoplastics. In Proceedings of the 12th International Conference on Textile Composites, Raleigh, NC, USA, $26-29$ May 2015.

29. Lyu, X.; Takahashi, J.; Wan, Y. Analysis of viscoelastic behaviour of ultra-thin chopped carbon fiber tape reinforced thermoplastics with different tape lengths. In Proceedings of the 17th European Conference on Composite Materials, Munich, Germany, 26-30 June 2016.

30. Meng, L.; Wataki, H.; Ohsawa, I.; Takahashi, J. Failure analysis of ultra-thin chopped carbon fiber tape reinforced thermoplastic in mechanical joints. In Proceedings of the 17th European Conference on Composite Materials, Munich, Germany, 26-30 June 2016

31. Nakashima, Y.; Suganuma, H.; Yamashita, S.; Takahashi, J. Evaluation of flexural modulus of ultra-thin chopped carbon fiber tape reinforced thermoplastics. In Proceedings of the 17th European Conference on Composite Materials, Munich, Germany, 26-30 June 2016.

32. Wan, Y.; Takahashi, J. Tensile and compressive properties of chopped carbon fiber tapes reinforced thermoplastics with different fiber lengths and molding pressures. Compos. Part A Appl. Sci. Manuf. 2016, 87, 271-281. [CrossRef]

33. Wan, Y.; Takahashi, J. Tensile properties and aspect ratio simulation of transversely isotropic discontinuous carbon fiber reinforced thermoplastics. Compos. Sci. Technol. 2016, 137, 167-176. [CrossRef]

34. Yamashita, S.; Hashimoto, K.; Suganuma, H.; Takahashi, J. Experimental characterization of the tensile failure mode of ultra-thin chopped carbon fiber tape-reinforced thermoplastics. J. Reinf. Plast. Compos. 2016, 35, 1342-1352. [CrossRef]

35. Lee, H.; Bi, C.; Tang, S.; Hayashi, T.; Takahashi, J. Formability and flow front observation of carbon/polyamide 6 randomly oriented strand composites during compression molding. J. Reinf. Plast. Compos. 2017, 36, 1727-1744. [CrossRef]

36. Nakashima, Y.; Yamashita, S.; Zhang, X.; Suganuma, H.; Takahashi, J. Analytical modelling of the behaviour and scatter of the flexural modulus of randomly oriented carbon fibre strand thermoplastic composites. Compos. Struct. 2017, 178, 217-224. [CrossRef]

37. Sato, W.; Shida, R.; Toyoda, H.; Fujita, M.; Takahashi, J. Verification of flexural rigidity of thickness optimized structure made of discontinuous CFRTP. In Proceedings of the 21st International Conference on Composite Materials, Xi'an, China, 20-25 August 2017.

38. Qu, P.; Wan, Y.; Bao, C.; Sun, Q.; Fang, G.; Takahashi, J. A new numerical method for the mechanical analysis of chopped carbon fiber tape-reinforced thermoplastics. Compos. Struct. 2018, 201, 857-866. [CrossRef]

39. Meng, L.; Wan, Y.; Ohsawa, I.; Takahashi, J. Effects of geometric parameters on the failure behavior of mechanically fastened chopped carbon fiber tape reinforced thermoplastics. Compos. Struct. 2019, 229, 111475. [CrossRef]

40. Wan, Y.; Takahashi, J. Mechanical modeling of CF/PA6 sheet molding compounds with X-ray computed tomography-based internal geometry considerations. Compos. Sci. Technol. 2020, 192, 108104. [CrossRef]

41. Wan, Y.; Takahashi, J.; Ohsawa, I. Investigation about the springback effect on short fiber reinforced thermoplastics. In Proceedings of the 13th Japan International SAMPE Symposium \& Exhibition, Nagoya, Japan, 6-8 November 2013.

42. Wan, Y.; Takahashi, J. Thermal deformation caused by residual stress in short fiber reinforced thermoplastics. In Proceedings of the SEICO 14 SAMPE EUROPE 35th International Conference and Forum, Paris, France, 11 March 2014.

43. Wan, Y.; Takahashi, J. Deconsolidation behavior of carbon fiber reinforced thermoplastics. J. Reinf. Plast. Compos. 2014, 33, 1613-1624. [CrossRef]

44. Lee, H.; Ohsawa, I.; Takahashi, J. Effect of plasma surface treatment of recycled carbon fiber on carbon fiber-reinforced plastics (CFRP) interfacial properties. Appl. Surf. Sci. 2015, 328, 241-246. [CrossRef]

45. Kobayashi, D.; Nakamura, T.; Wan, Y.; Ohsawa, I.; Takahashi, J. A study on hybridization of springbacked carbon fiber reinforced thermoplastics. In Proceedings of the 21st International Conference on Composite Materials, Xi'an, China, 20-25 August 2017.

46. Zhang, Y.; Wan, Y.; Nakamura, T.; Takahashi, J. Effect of springback ratio on bending and impact property of carbon fiber reinforced thermoplastics sandwich structures. In Proceedings of the 21st International Conference on Composite Materials, Xi'an, China, 20-25 August 2017.

47. Wei, H.; Nagatsuka, W.; Lee, H.; Ohsawa, I.; Sumimoto, K.; Wan, Y.; Takahashi, J. Mechanical properties of carbon fiber paper reinforced thermoplastics using mixed discontinuous recycled carbon fibers. Adv. Compos. Mater. 2018, 27, 19-34. [CrossRef] 
48. Li, J.; Xiao, B.; Matsuda, H.; Wan, Y.; Ohsawa, I.; Takahashi, J. Flexural property and energy absorption ability of CPT/AWT hybrid composites. In Proceedings of the 16th Japan international SAMPE symposium and exhibition, Tokyo, Japan, 2-6 September 2019.

49. Matsuda, H.; Xiao, B.; Ohsawa, I.; Takahashi, J. Effect of aramid fiber cloth on carbon/aramid fiber reinforced thermoplastics. In Proceedings of the 22nd international conference on Composite Materials, Melbourne, Australia, 11-16 August 2019.

50. Wei, H.; Nagatsuka, W.; Ohsawa, I.; Sumimoto, K.; Takahashi, J. Influence of small amount of glass fibers on mechanical properties of discontinuous recycled carbon fiber-reinforced thermoplastics. Adv. Compos. Mater. 2019, 28, 321-334. [CrossRef]

51. Xiao, B.; Wan, Y.; Ohsawa, I.; Takahashi, J. Effect of needle punching on flexural behavior of carbon fiber-reinforced thermoplastic sandwich panel with spring-backed core. Compos. Part A Appl. Sci. Manuf. 2019, 118, 57-66. [CrossRef]

52. Wei, H.; Akiyama, T.; Lee, H.; Yamane, M.; Takahashi, J.; Ohsawa, I.; Murakami, T.; Kawabe, K. Recycling of market CFRP/CFRTP waste for mass production application. In Proceedings of the 19th international Conference on Composite Materials, Montréal, QC, Canada, 28 July-2 August 2013; pp. 8574-8581.

53. Wei, H.; Akiyama, T.; Lee, H.; Ohsawa, I.; Takahashi, J. Mechanical properties of recycled carbon fiber reinforced thermoplastics made by carbon fiber paper. In Proceedings of the 16th European Conference on Composite Materials, Seville, Spain, 22-26 June 2014.

54. Wei, H.; Lee, H.; Nagatsuka, W.; Ohsawa, I.; Kawabe, K.; Murakami, T.; Sumitomo, T.; Takahashi, J. Systematic comparison between carding and paper-making method for producing discontinuous recycled carbon fiber reinforced thermoplastics. In Proceedings of the 20th International Conference on Composite Materials, Copenhagen, Denmark, 19-24 July 2015 ; pp. 1-9.

55. Okano, N.; Wei, H.; Cai, G.; Wada, M.; Kitaoka, S.; Takahashi, J. Influence of recycling condition on the scatter of CFRP properties. In Proceedings of the 21st International Conference on Composite Materials, Xi'an, China, 20-25 August 2017.

56. Yin, G.; Cai, G.; Wei, H.; Nagatsuka, W.; Kohira, T.; Morisawa, J.; Takahashi, J. Novel carding process to improve mechanical properties of recycled carbon fiber card web reinforced thermoplastics. In Proceedings of the 21st International Conference on Composite Materials, Xi'an, China, 20-25 August 2017.

57. Zhang, Y.; Yin, G.; Xiao, B.; Wan, Y.; Ohsawa, I.; Takahashi, J. Comparison between springbacked carbon fiber card web reinforced thermoplastics and carbon fiber paper reinforced thermoplastics sandwich structures on bending and impact property. In Proceedings of the 18th European Conference on Composite Materials, Athens, Greece, 25-28 June 2018.

58. Furuta, Y.; Shao, S.; Yin, G.; Xiao, B.; Wan, Y.; Takahashi, J. Design of semi-complex parts using anisotropic carbon fiber card web reinforced thermoplastics. In Proceedings of the 22nd international conference on Composite Materials, Melbourne, Australia, 11-16 August 2019.

59. Xiao, B.; Zaima, T.; Shindo, K.; Kohira, T.; Morisawa, J.; Wan, Y.; Yin, G.; Ohsawa, I.; Takahashi, J. Characterization and elastic property modeling of discontinuous carbon fiber reinforced thermoplastics prepared by a carding and stretching system using treated carbon fibers. Compos. Part A Appl. Sci. Manuf. 2019, 126, 105598. [CrossRef]

60. Wan, Y.; Straumit, I.; Takahashi, J.; Lomov, S.V. Micro-CT analysis of internal geometry of chopped carbon fiber tapes reinforced thermoplastics. Compos. Part A Appl. Sci. Manuf. 2016, 91 Pt 1, 211-221. [CrossRef]

61. Wan, Y.; Straumit, I.; Takahashi, J.; Lomov, S.V. Micro-CT analysis of the orientation unevenness in randomly chopped strand composites in relation to the strand length. Compos. Struct. 2018, 206, 865-875. [CrossRef]

62. Yamashita, S.; Ohsawa, I.; Morita, A.; Takahashi, J. Fracture behavior of carbon fiber reinforced polypropylene under artificial lightning strike. In Proceedings of the 19th international Conference on Composite Materials, Montréal, QC, Canada, 28 July-2 August 2013; pp. 6940-6948.

63. Nagatsuka, W.; Wada, M.; Ohsawa, I.; Kitaoka, S.; Takahashi, J. Influence of Superheated Steam Treatment Condition on Recycled Carbon Fiber. In Proceedings of the 1st International Symposium on Emerging Functional Materials, Songdo, Korea, 4-6 November 2015.

64. Cai, G.; Yin, G.; Wada, M.; Kitaoka, S.; Wei, H.; Ohsawa, I.; Takahashi, J. Influence of recycling process on the tensile property of carbon fiber. In Proceedings of the 21st International Conference on Composite Materials, Xi'an, China, 20-25 August 2017.

65. Cai, G.; Wada, M.; Ohsawa, I.; Kitaoka, S.; Takahashi, J. Influence of treatment with superheated steam on tensile properties of carbon fiber. Compos. Part A Appl. Sci. Manuf. 2018, 107, 555-560. [CrossRef]

66. Cai, G.; Wada, M.; Ohsawa, I.; Kitaoka, S.; Takahashi, J. Interfacial adhesion of recycled carbon fibers to polypropylene resin: Effect of superheated steam on the surface chemical state of carbon fiber. Compos. Part A Appl. Sci. Manuf. 2019, 120, 33-40. [CrossRef]

67. Cai, G.; Wada, M.; Ohsawa, I.; Kitaoka, S.; Takahashi, J. Tensile properties of recycled carbon fibers subjected to superheated steam treatment under various conditions. Compos. Part A Appl. Sci. Manuf. 2020, 133, 105869. [CrossRef]

68. Wan, Y.; Matsuo, T.; Ohsawa, I.; Takahashi, J. Effects of curvature on strength and damage modes of L-shaped carbon fiberreinforced polypropylene. J. Reinf. Plast. Compos. 2014, 33, 1305-1315. [CrossRef]

69. Matsuo, T.; Goto, T.; Takahashi, J. Investigation about the fracture behavior and strength in a curved section of CF/PP composite by a thin-curved beam specimen. Adv. Compos. Mater. 2015, 24, 249-268. [CrossRef]

70. Ohori, T.; Hayashi, T.; Takahashi, J. FEA using design optimization technique for an application of carbon fiber reinforced thermoplastics to automobile body structure. In Proceedings of the 20th International Conference on Composite Materials, Copenhagen, Denmark, 19-24 July 2015; pp. 1-10.

71. Guo, Q.; Li, Z.H.; Ohori, T.; Takahashi, J. Design optimization of CFRP rectangular box subjected to arbitrary loadings. In Proceedings of the 17th European Conference on Composite Materials, Munich, Germany, 26-30 June 2016. 
72. Fujita, M.; Nakashima, Y.; Takahashi, J. Influence of strand dispersion method on mechanical properties of hollow-S-shaped member made of randomly-orientated CFRTP strands. In Proceedings of the 21st International Conference on Composite Materials, Xi'an, China, 20-25 August 2017.

73. Shida, R.; Takahashi, J. Theoretical analysis on CFRTP optimal structure subjected to bending load and the influence of outof-plane shear modulus. In Proceedings of the 21st International Conference on Composite Materials, Xi'an, China, 20-25 August 2017.

74. Toyoda, H.; Suganuma, H.; Yamashita, S.; Hayashi, T.; Fujita, M.; Takahashi, J. Influence of strand dimension and dispersion method on rigidity and its scatter of hat shaped specimens made of randomly-oriented CFRTP strands. In Proceedings of the 21st International Conference on Composite Materials, Xi'an, China, 20-25 August 2017.

75. Guo, Q.; Ohsawa, I.; Takahashi, J. L-shaped structures made from ultrathin chopped carbon fiber tape reinforced thermoplastics: Delamination behavior and optimization. Adv. Compos. Mater. 2019, 28, 479-489. [CrossRef]

76. Guo, Q.; Ohsawa, I.; Takahashi, J. Experimental and Numerical Investigation of Mode I and Mode II Interlaminar Behavior of Ultra-Thin Chopped Carbon Fiber Tape-Reinforced Thermoplastics. Arab. J. Sci. Eng. 2020, 45, 1071-1080. [CrossRef]

77. Guo, Q.; Xiao, B.; Ohsawa, I.; Takahashi, J. Fracture mechanism characteristics of ultra-thin chopped carbon fiber tape-reinforced thermoplastics hat-shaped hollow beam under transverse static and impact loadings. Carbon Lett. 2020, 30, 271-280. [CrossRef]

78. Mittal, G.; Rhee, K.Y.; Miskovic-Stankovic, V.; Hui, D. Reinforcements in multi-scale polymer composites: Processing, properties, and applications. Compos. Part B Eng. 2018, 138, 122-139. [CrossRef]

79. Lyu, X.; Ohsawa, I.; Takahashi, J. Applicability of a tapping method to non-destructive inspection of carbon fiber reinforced thermoplastics. In Proceedings of the 20th International Conference on Composite Materials, Copenhagen, Denmark, 19-24 July 2015; pp. 1-12.

80. Yamashita, S.; Nakashima, Y.; Takahashi, J.; Kawabe, K.; Murakami, T. Tape length dependence of the electrical conductivity of ultra-thin chopped carbon fiber tape reinforced thermoplastics. In Proceedings of the 14th Japan International SAMPE Symposium and Exhibition, Kanazawa, Japan, 6-9 December 2015.

81. Yamashita, S.; Nakashima, Y.; Takahashi, J.; Kawabe, K.; Murakami, T. Volume resistivity of ultra-thin chopped carbon fiber tape reinforced thermoplastics. Compos. Part A Appl. Sci. Manuf. 2016, 90, 598-605. [CrossRef]

82. Hayashi, T.; Kobayashi, T.; Takahashi, J. Quantification of the void content of Composite Materials using soft X-ray transmittance. J. Thermoplast. Compos. 2017, 30, 1522-1540. [CrossRef]

83. Yamashita, S.; Sonehara, T.; Takahashi, J.; Kawabe, K.; Murakami, T. Effect of thin-ply on damage behaviour of continuous and discontinuous carbon fibre reinforced thermoplastics subjected to simulated lightning strike. Compos. Part A Appl. Sci. Manuf. 2017, 95, 132-140. [CrossRef]

84. Lyu, X.; Takahashi, J.; Wan, Y.; Ohsawa, I. Determination of transverse flexural and shear moduli of chopped carbon fiber tape-reinforced thermoplastic by vibration. J. Compos. Mater. 2018, 52, 395-404. [CrossRef]

85. Lyu, X.; Wan, Y.; Takahashi, J.; Ohsawa, I. Health condition evaluation of carbon fiber-reinforced thermoplastic with a tapping system. J. Thermoplast. Compos. 2018, 31, 959-973. [CrossRef]

86. Toyoda, H.; Sato, W.; Takahashi, J. Effect of thermal welding repair for damaged ultrathin chopped carbon fiber tape reinforced thermoplastics. In Proceedings of the 18th European Conference on Composite Materials, Athens, Greece, 25-28 June 2018.

87. Piao, H.; Chen, L.; Kiryu, Y.; Ohsawa, I.; Takahashi, J. Influence of Water Absorption and Temperature on the Mechanical Properties of Discontinuous Carbon Fiber Reinforced Polyamide 6. Fibers Polym. 2019, 20, 611-619. [CrossRef]

88. Piao, H.; Kiryu, Y.; Chen, L.; Yamashita, S.; Ohsawa, I.; Takahashi, J. Influence of water absorption on the mechanical properties of discontinuous carbon fiber reinforced polyamide 6. J. Polym. Res. 2019, 26, 63. [CrossRef]

89. Zhang, J.; Chevali, V.S.; Wang, H.; Wang, C.H. Current status of carbon fibre and carbon fibre composites recycling. Compos. Part B Eng. 2020, 193, 15. [CrossRef] 